\title{
FLUTUAÇÕES DA INCIDÊNCIA DA FEBRE AFTOSA EM BOVINOS NO ESTADO DO RIO GRANDE DO SUL
}

\author{
PEDRO CARVALHO RODRIGUES \\ Médico Veterinário
}

Orientador: Prof. Dr. CLOVIS POMPILIO DE ABREU

\begin{abstract}
Tese apresentada à Escola Superior de Agricultura "Luiz de Quei. roz", da Universidade de São Paulo, para obtenção do título de Doutor em Agronomia. Área de Concentração: Estatística e Experimentação Agronômica.
\end{abstract}

PIRACICABA

Estado de São Paulo - Brasil

Dezembro, 1982 


\section{AGRADECIMENTOS}

Ao Dr. Clövis Pompílio de Abreu, Professor do Departamento de Matemática e Estatística da Escola Superior de Agricultu ra "Luiz de Queiroz", pela orientação e amizade dedicada.

Ao Dr. Frederico Pimentel Gomes, Professor do Departamento de Matemätica e Estatística da ESALQ, pela amizade e estima. Ao Dr. Humberto de Campos, Coordenador do Curso de Pós-Graduação em Estatistica e Experimentação Agronômica, nossa admiração pelas lições de humanidade.

Ao Dr. Décio Barbin, Professor do Departamento de Ma temática e Estatística da ESAIQ, pela ajuda e revisão inestimáveis.

Ao Dr. Vicente Astudillo, Bioestatístico do Centro Panamericano de Febre Aftosa - RJ, pela ajuda inestimável e amizade. A Prof ${ }^{a}$. Georgina do Nascimento Marçal, pela valiosa ajuda na revisão desta obra.

Ao Dr. Antonio Francisco Iemma, muito grato pelas va liosas sugestões apresentadas.

Ao Prof. Jacintho Machado Mendonça Júnior, ex-Diretor da Faculdade de Veterināria da Universidade Federal Fluminense, minha gratidão (in memoriom).

Ao Dr. Evaldo de Oliveira, Chefe do Departamento de Saūde da Comunidade, Faculdade de Medicina, da Universidade Federal Fluminense, pelo apoio dispensado. 
Aos Professores e Funcionários do Departamento de Ma temātica e Estatística da ESALQ, pelo bom convívio e companheirismo. Ao Funcionário Antonio José Mendes da Silva, do Centro Panamericano de Febre Aftosa - RJ, pela ajuda dispensada na obtenção dos dados.

A CAPES (Comissão de Aperfeiçoamento de Pessoal de Nível Superior), pela bolsa de estudos concedida durante a realização do Curso.

A Srta. Maria Izalina Ferreira Alves, pelos serviços datilogräficos.

Aos colegas do Curso de Pós-Graduação, pela satisfação que tive em conhecê-los.

A todos que de uma maneira ou de outra colaboraram na realização deste trabalho. 


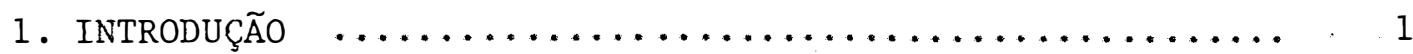

2. REVISÃO DE LITERATURA $\ldots \ldots \ldots \ldots \ldots \ldots \ldots \ldots \ldots \ldots \ldots \ldots$

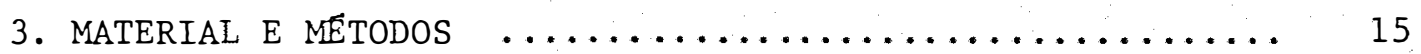

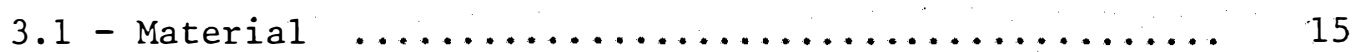

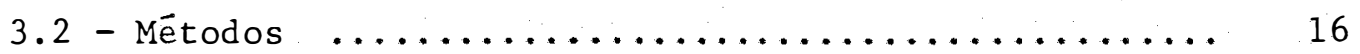

3.2.1 - Bezerros menores de 4 meses $\left(n_{1}\right) \ldots \ldots \ldots 16$

3.2.2 - Bezerros maiores de 4 meses e menores de 1 ano $\left(\mathrm{n}_{2}\right) \quad \ldots \ldots \ldots \ldots \ldots \ldots \ldots \ldots \ldots \ldots \ldots \ldots \ldots \ldots \ldots \ldots$

3.2 .3 - Bovinos jovens $\left(n_{3}\right) \quad \ldots \ldots \ldots \ldots \ldots \ldots \ldots \ldots \ldots \ldots$

3.2 .4 - Bovinos adultos $\left(n_{4}\right) \ldots \ldots \ldots \ldots \ldots \ldots .17$

3.3 - Indices Mensais $\ldots \ldots \ldots \ldots \ldots \ldots \ldots \ldots \ldots \ldots . \ldots \ldots \ldots$

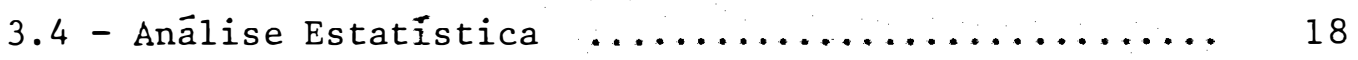

3.4.1 - Coeficientes de correlação e de determinação 18

3.4 .2 - Equações de regressão linear simples e múl-

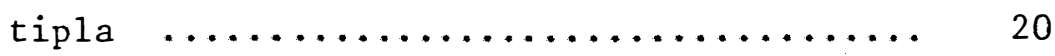

3.4 .3 - Anālise da variância ................. 22

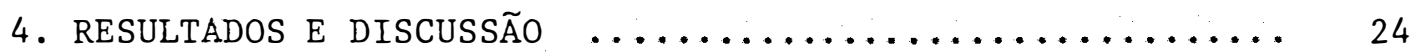

4.1 - Anālises de Regressão e de Correlação .......... 24

4.2 - Anālise da variância $\ldots \ldots \ldots \ldots \ldots \ldots \ldots \ldots \ldots . .6 \ldots$

4.2.1 - Comparação dos anos e meses $\ldots \ldots \ldots \ldots \ldots \quad 38$

4.3 - Teste de Duncan $\ldots \ldots \ldots \ldots \ldots \ldots \ldots \ldots \ldots \ldots . ., 40$ 
vi.

Pág.

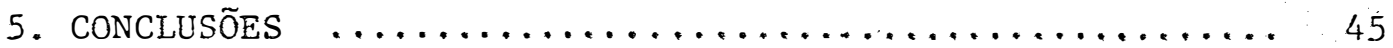

6. LITERATURA CITADA $\ldots \ldots \ldots \ldots \ldots \ldots \ldots \ldots \ldots \ldots \ldots \ldots \ldots \ldots \ldots$

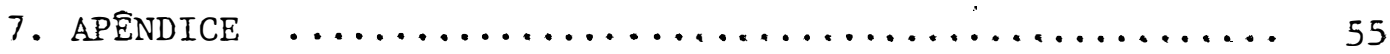




\section{LISTA DE TABELAS}

\section{TABELA}

1 Movimentação de animais, nível de imunização estimado e número de focos confirmados. Rio Grande do Sul, 1973

2 Movimentação de animais, nível de imunização estimado e número de focos confirmados. Rio Grande do Sul, 1974

3 Movimentação de animais, nível de imunização estimado e número de focos confirmados. Rio Grande do Sul, 1975

4 Movimentação de animais, nível de imunização estimado e número de focos confirmados. Rio Grande do Sul, 1976

5 Movimentação de animais, nîvel de imunização estimado e número de focos confirmados. Rio Grande do Sul, 1977

6 Movimentação de animais, nível de imunização estimado e nümero de focos confirmados. Rio Grande do Sul, 1978

7 Movimentação de animais, nível de imunização estimado e número de focos confirmados. Rio Grande do Sul, 1979 
viii.

TABELA

Pāg.

8 Movimentação de anjmais, nível de imunização estimado e número de focos confirmados. Rio Grande do Sul, 1980

9 Médias dos meses do período quanto à movimentação de animais, nível de imunização estimado e número de fo cos confirmados. Rio Grande do Sul, 1973-1980 ....

10 Movimentação de anjmais, nível de imunização estimado e número de focos confirmados, nos meses do perío do, considerados de baixa frequência. Rio Grande do Sul $1973-1980 \ldots \ldots \ldots \ldots \ldots \ldots \ldots \ldots \ldots \ldots \ldots \ldots$

11 Movimentação de animais, nível de imunização estimado e nümero de focos confirmados, nos meses do perío do, considerados de alta frequência. Rio Grande do

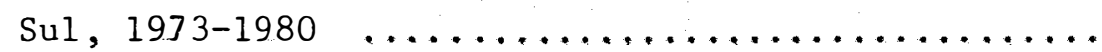

12 Número de focos confirmados de febre aftosa. Rio Gran de do Sul, 19J3-1980 $\ldots \ldots \ldots \ldots \ldots \ldots \ldots \ldots \ldots \ldots \ldots \ldots \ldots \ldots \ldots$ 


\title{
FLUTUAÇÕES DA INCIDENCIA DA FEBRE AFTOSA EM BOVINOS NO ESTADO DO RIO GRANDE DO SUL
}

\author{
Autor: Pedro Carvalho Rodrigues \\ Orientador: Dr. Clóvis Pompílio de Abreu
}

\section{$R$ E S U M O}

o autor se propôs a estudar a incidência de focos de febre aftosa em bovinos no Estado do Rio Grande do Sul - Brasil, ve rificando a influência da movimentação de animais e do nível de imu nização adquirido através da vacinação, sobre o aparecimento da doen ça. Para essas variāveis foram feitas observações mensais, no perío do referente aos anos de 1973 a 1980 .

Nas anālises de correlação e regressão linear simples e múltipla, foram ratificadas citações de alguns autores, evidenciando-se que nas fases da doença, consideradas endêmicas, a movimentação de animais teve uma contribuição decisiva no aumento da in cidência, enquanto que nas fases consideradas epidêmicas não foi tão evidente sua influência. 
Através da anālise da variância, foi também evidenciado o fato de que houve, naquele período, um declínio na incidên cia de focos, possivelmente decorrente de medidas de controle adotadas naquele Estado. 


\section{FLUCTUATIONS IN THE INCIDENCE OF FOOT-AND-MOUTH \\ DISEASE IN BOVINE CATTLE IN THE STATE OF \\ RIO GRANDE DO SUL}

$\begin{array}{ll}\text { Author: } & \text { Pedro Carvalho Rodrigues } \\ \text { Adviser: } & \text { Dr. Clóvis Pompílio de Abreu }\end{array}$

$S U M M A R Y$

The author's purpose is to study the incidence of Foot-Mouth-Disease outbreaks in bovine cattle, in the State of Rio Grande do Sul - Brazil, verifying the influence of aminal movements and the level of immunization acquired from vaccination on the number of outbreaks of the disease.

The study used monthly observations of these variables from 1973 to 1980 .

Analyses of correlation, linear and multiple regression ratified several authors citations and made evident that during the phases considered endemic, the movement of animal do greatly contributed to increase the incidence. Meanwhile, during the phases considered epidemic there was not such a clear evidence of the effect of animal movement on the number of outbreaks. 
Analysis of variance showed that during that period occurred a significant decrease in the number of outbreaks, possibly due to control measures adopted by the State of Rio Grande do Sul. 
FLUCTUATIONS DE L'INCIDENCE DE'LA FIEVRE APHTEUSE SUR DES BOVINS DANS L'ETAT DE RIO GRANDE DO SUL

Auteur: Pedro Carvalho Rodrigues

Orienteur: Dr. Clóvis Pompilio de Abreu

\section{RE S U M E}

L'auteur s'est proposé à étudier l'incidence de foyers de fièvre aphteuse sur des bovins dans 1'Etat de Rio Grande do Sul Brésil. L'objectif du travail est vérifier l'influence de la mouvemen tation des animaux et du niveau immunitaire acquis à travers la vacci nation, sur l'apparition de la maladie. La période d'étude, avec des observations mensuelles des variables, se rapporte aux années de 1973 à 1980.

A travers les analyses de corrélation, régression linéaire et multiple, des citations de plusieurs auteurs sont ratifieés, en mettant en evidence que, pendant les phasés considéreés endémiques, la mouvementation des animaux a contribué, décisivement, à l'augmentation de l'incidence. Son influence, cependant, n'a pas eté si évidente dans les phases considéreés epidémiques. 
L'analyse de variance a rendu claire qu'il y a un, dans la période, un déclin de l'incidence de foyers, probablement à cause des mesures de controle, mises en pratique dans cet Etat. 


\title{
FLUCTUACIONES DE LA INCIDENCIA DE LA FIEBRE AFTOSA
}

\section{EN BOVINOS EN EL ESTADO DE RIO GRANDE DO SUL}

\author{
Autor: $\quad$ Pedro Carvalho Rodrigues \\ Orientador: Dr. Clóvis Pompilio de Abreu
}

\section{R E S U M N}

El autor se propone estudiar la incidencia de la fie bre aftosa en bovinos en el Estado de Rio Grande do Sul - Brasil,ve rificando la influencia del trânsito de animales y del nivel inmuni tario adquirido a través de la vacunación, sobre la ocurrencia de la enfermedad. Para esas variables fueron hechos observaciones mensuales, en el período 1973 a 1980.

En las anälises de regresion y correlacion linear sim ple y múltiple, fueron ratificadas observaciones de algunos autores, poniendo-se en evidencia que en las fases consideradas endémicas de la enfermedad, el trânsito de animales tiene una contribución decisiva en el aumento de la incidencia en cuanto que en las fases consideradas epidémicas, no ès tan evidence su influencia. 
xvi.

A través del análisis de la varianza fue también verificado el hecho de que en el período de este estudio hubo un descenso en la ocurrencia de focos, posiblemente a consecuencia de las medidas de control adoptadas en aquel Estado. 
1. INTRODUÇÃO

A ocorrência da febre aftosa no Brasil, segundo ROSENBERG e GOIC (1973), data de 1870. Isto aconteceu a partir da importação de bovinos da Europa.

Trata-se de uma enfermidade que tem frequência endêmica em todo o Brasil. Ela aparece sob forma benigna em animais adultos e jovens, com pequena taxa de mortalidade em relação aos an mais jovens. A febre aftosa, entre as doenças que atacam os nossos rebanhos, é das mais importantes do ponto de vista econômico.

Em 1964, o Estado do Rio Grande do Sul iniciava os trabalhos de combate à febre aftosa. 'Passou, a partir desse instante, a ser considerada unidade pioneira da Federação. Em dezembro de 1965, iniciou-se o Plano Éstadual de Combate à Febre Aftosa. Este 
Plano foi executado por etapas, e no ano de 1971 atingiu todo o Estado, incorporando-se ao Plano Nacional de Combate à Febre Aftosa do Ministério da Agricultura do Brasil, com apoio financeiro do BID. Julgou-se oportuno estudar algumas características da doença, considerando os prejuízos econômicos que sua ocorrência acar reta, e o Estado do Rio Grande do Sul foi selecionado para o presen te estudo, por possuir um sistema de informações que possibilita a investigação e, sobretudo, por ter na pecuária uma de suas principais fontes de exploração econômica. Esta atividade ocupa 55\% da ārea total do Estado, tendo a bovinocultura papel de destaque, com um total de 12.264 .000 cabeças.

o objetivo deste trabalho foi o de verificar a influência da movimentação de animais, tanto para abate como para o ciclo pecuärio (cria, recria e engorda), e o nível de imunização por eles adquirido através de vacinações, em relação à ocorrência de fó $\cos$ da febre aftosa.

vārios são os fatores de difusão da doença; a movimentação de animais para locais de feiras, exposições e leilões, com grande concentração de gado proveniente de diversas regiões, e o in tenso e crescente deslocamento de animais por vastas äreas. Acrescente-se a essa movimentação o fato de que a doença pode ser provocada por três tipos de virus, O, A e C, com grande variabilidade do vírus $\mathrm{A}$.

Considerou-se que o éxito no combate à febre aftosa depende da estratégia de ação. Esta consiste em especial atenção ês 
atividades de controle de focos, interdição de propriedades, contro le de trânsito de animais, produção e controle de vacinas, vacinação, educação sanitāria, treinamento de pessoal, informação estatís tica, divulgação e avaliação do programa.

Para se obter o controle da febre aftosa, faz-se necessārio a colaboração permanente e integrada dos setores políticos, técnicos e produtores. Nesta cooperação mútua, repousam as possibilidades de sucesso do empreendimento.

A implantação de projetos para combate à doença obję tiva redução de perdas físicas na produção, ampliação de mercados in ternacionais e abertura de novos, maior disponibilidade de proteínas para alimentação humana e aumento do mercado de trabalho. Assim, entendeu-se que são inúmeras as vantagens desse programa.

Com base no objetivo traçado, buscou-se oferecermaio res informações através dos dados apresentados, e avaliar a influên cia das características indicadas em relação à ocorrência da febre aftosa. Por fim, recomendar medidas que diminuam sua frequência. 


\section{REVISATO DE LITERATURA}

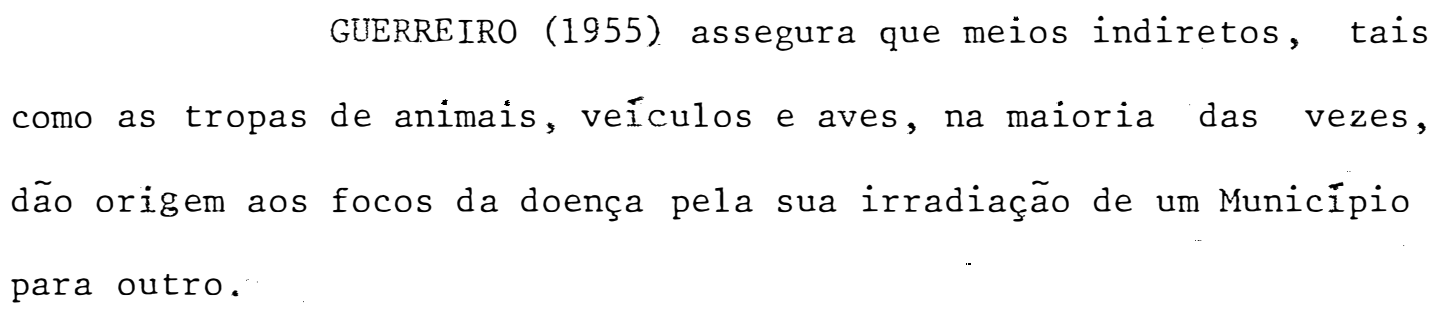

ADEMOLLO (1959) resume os pontos importantes para o controle veterinārio que se exerce nos aeroportos, tais como: a vigilância veterinária permanente e a destruição dos resíduos alimentares provenientes de bordo. Os restos de produtos de origem animal podem propagar doenças, dentre elas a febre aftosa. Julga-se, assim, de grande importância, o cumprimento rigoroso destas medidas. Só des te modo pode-se evitar a entrada de vírus através dessas possíveis fontes de contaminação.

$$
\text { MACKOWIAK et alii (1962) ressaltam haver uma relação }
$$


entre a duração da imunidade e as doses de vacina aplicadas. A imunidade é mais sólida (duração em torno de um ano) quando a revacina ção for feita com doses iguais e não ultrapassar o prazo de três a quatro meses após a primeira aplicação.

BEKKUM et alii (1963) observaram, em experimento, que os títulos de anticorpos neutralizantes contra os tipos 0 , A e C, aplicados durante 107 semanas com intervalos de 3 meses, tiveram,ao final da experiência, nos soros, seus títulos com altos valores de anticorpos .

SCHNEIDER et alii (1964) aplicaram doses de $5 \mathrm{ml}$ de vacinas antiaftosa em 100 bovinos, com 2 a 3 anos de idade. Tinham como objetivo observar a duração da imunidade. Verificaram que o po der imunizante, no período de 15 a 17 dias após a vacinação,foi con siderado bom, atingindo o título de 1:900 de soroneutralização.

PARDI e CALDAS (1968) atestam o predomínio absoluto do gado de corte no rebanho bovino gaúcho. Isto constitui fator importante na propagação da doença, devido ao maior movimento de animais para fins comerciais. Por outro lado, a ocorrência da doença é menos frequente nos animais produtores de leite, animais de pouca movimentação.

BEKKUM et alii (1969), em experimento realizado, observaram que os títulos de anticorpos neutralizantes contra os tipos 0 , A e C, de febre aftosa, persistem 4 anos ou mais na maioria do gado bovino que recebeu duas ou mais vacinações anuais. 
LUCAM et alii (1969) relatam que a evolução e a dura ção da imunidade antiaftosa, em animais vacinados pela primeira vez, dependem da eficácia da vacina, ou seja, da magnitude que alcança a imunidade 30 dias após a vacinação. A esta imunidade denominou-se "imediata". Quando ela é superior (dada pelo $\log K=1,2$ ) a percentagem de proteção fica acima de $80 \%$. Entretanto, quando é inferior àquele valor, com 60 ou 90 dias apōs a vacinação, a imunidade é pra ticamente nula.

MUNTIU (1969) e MUNTIU et alii (1969) enfatizam que a imunidade, apōs a vacinação contra a febre aftosa, depende de mui tos outros fatores. São muito importantes, também, a resistência e o estado nutricional do animal. Menor influência exercem a época do ano, o frio, o calor e o esforço físico.

BEKKUM (1970) admite que apenas uma dose de vacina é insuficiente para produzir o nümero de anticorpos necessários a fim de que o animal adquira imunidade à doença. Frisa que a vacinação repetida ē indispensável em qualquer programa de vacinação a longo prazo.

CALLIS (1970) relata que há emprego de dois tipos de vacina contra a febre aftosa: a de vírus inativado e a de vírus modificado. Ressalta que os países exportadores utilizam vacina do ti po inativado, porque os países importadores não aceitam a carne quan do os animais são vacinados com emprego do vírus modificado. Esta atitude é causada pelo temor de que os produtos contenham o vírus. 
HONIGMAN et alii (1971) evidenciam que a vacinação irregular è um dos maiores problemas na imunização dos animais jovens em qualquer campanha para controle da febre aftosa. Admitem que a revacinação, a intervalos curtos de tempo, em bovinos jovens, é fator relevante para que eles adquiram nível de imunização mais sōlido. Esclarecem, contudo, que na prática esta medida não se realiza.

Deve-se salientar que, no Rio Grande do Sul, a vacinação ē feita de 4 em 4 meses.

BACHRACH (1972) ressalta que os bovinos apresentam, apōs a infeç̧ão da febre aftosa, recuperação completa. Um certo nümero de animais, porém, torna-se, durante longo tempo, portador do vírus. Constituem, assim, novos focos da doença.

Observa-se, algumas vezes, tanto nesses animais como nos que foram vacinados, um indice de soro proteção que os tornam imunes à doença.

CHAPPUIS e MOREAU (1972) indicam os resultados de uma experiência realizada. Os bovinos, após a primeira vacinação, apresentam um índice de soro proteção de 0,95. Seis meses após,quando re vacinados, tiveram seu indice elevado para 1,62. Isto reflete maior proteção frente ao vírus aftoso. Eis porque considera-se que as vaci nações repetidas conferem aos animais maior índice de soro proteção. Este vai num crescendo, atê atingir um valor que torna os animais resistentes ao contágio com o vírus. 
FEDIDA et alii (1972) concluiram que as revacinações de bovinos - feitas com intervalos que variam de 4 meses a 1 ano e, neste último caso, repetida durante alguns anos - conferem uma imu nidade caracterizada sob o ponto de vista evolutivo. Deduziram também que, após cada revacinação, a imunidade é idêntica àquela que produziu a primeira vacinação do animal. Isto significa que ela se eleva, rapidamente, atingindo seu máximo na 3 . semana e diminuindo, em seguida, para se estabilizar por 3 a 4 meses em nível mais baixo. Isto corresponde ao que denomina-se de "imunidade residual".

A taxa de anticorpos, neste caso, apresenta uma boa percentagem de proteção.

FERNANDES (1972) afirma que, no desenvolvimento da pe cuária, no que se refere aos prejuízos produzidos pela febre aftosa, devem-se considerar as perdas causadas pelo transtorno do comércio normal de exportações de animais, matérias de origem animal e outros produtos agrícolas.

HUGH-JONES (1972) encontrou uma associação estatisti camente significativa entre a densidade da população bovina e a ocor rência da doença. Relata que durante os anos de 67-68, na Inglaterra, houve um incremento acentuado de focos com o aumento do tamanho do rebanho. Para este estudo foram considerados, quanto à densidade, 8 grupos, ou seja, desde 10-19 atē 80-89 animais por acre. HYSLOP (1972) considera que a difusão e a alta ocorrênciada enfermidade se manifestam acada dez anos, alterando com pe- 
ríodos de poucos focos. Nestes momentos, por razões econômicas, ocorre um relaxamento das medidas preventivas.

MOURAVIEV et alii (1972) revelam que a revacinação de termina uma imunidade sólida com duração média de 4 a 5 meses. Nos animais vacinados pela primeira vez a imunidade varia de 1 a 3 meses. O intervalo aumenta para 9 a 10 meses nos animais adultos. Citam os autores, ainda, uma correlação entre o nível de anticorpos neutralizantes e a resistência dos bovinos à contaminação intradermolingual pelo vírus aftoso.

MUNTIU et alii (1972) utilizaram 215 bovinos para in vestigar a duração da imunidade nos animais, e verificaram que uma única dose de 16 Dose Protetora 50/adultos induz a 8 meses de imuni dade em adultos e a 2 meses nos animais jovens. ROSENBERG e GOIC (1972) apontam, como objetivo prioritário, o uso exclusivo de vacinas de eficácia comprovada, no programa de luta contra a febre aftosa.

ASTUDILLO et alii (1973) apresentam os valores de al guns indicadores referentes à população bovina do Estado do Rio Gran de do Sul. Isto evidencia que o risco da ocorrência de febre aftosa é diferente ao considerarmos a característica idade.

Os indicadores citados são:

- população de menores de 1 ano: 195 x 10.000;

- população entre 1 e 2 anos: 225 x 10.000;

- população de maiores de 2 anos:161 x 10.000 . 
OLIVEIRA (1973) mostra que, no Rio Grande do Sul, após trabalhos desenvolvidos pela campanha contra febre aftosa, o in dice de letalidade que em 1966 era de 4,7\% baixou em 1968 para 0,25\%; a incidência da doença,que era de $1,65 \%$ em 1966 , diminuiu para $0,46 \%$ em 1972, evitando-se a morte de 232.000 animais naquele período.

Consideram-se estes resultados como fruto das medidas adotadas através do Plano Nacional de Combate à Febre Aftosa, instalado naquele Estado.

FERNĀNDEZ e SÖNDAHL (1975) relatam que animais jovens respondem de forma mais fraca e tardia do que os animais adultos à formação de anticorpos, isto em razão da presença de alto nível de imunoglobulinas circulantes que estão contidas no colostro, forneci do pelas mães.

LOBO (1975) fala do fenômeno de mudança das características do vírus em āreas enzoōticas. Esse é favorecido por diferentes condições - vacinação irregular ou falta desta, e presença de animais jovens com níveis deficientes de proteção. Isto explica o frequente aparecimento de novos subtipos dos vírus. ANSELMO et alii (1976) realizaram estudo em que demonstram, durante os dois anos de observação, a tendência para a di minuição da incidência quanto ao coeficiente da doença. Eles creditaram este fato ao programa de combate à febre aftosa que è levado a efeito na ärea. No período de 01/07/72 a 30/06/73, o coeficiente de incidência foi de 99,67/10.000 bovinos, passando a 38,08/10.000 
bovinos, no período de 01/07/73 a 30/06/74.

$$
\text { MÁLAGA et alii (1976) relatam que a enfermidade }
$$

se transmite, principalmente, por contato. Creem, também, que a pos sibilidade máxima de contāgio ocorre quando hā aumento de movimenta ção dos animais adultos, isto porque, possivelmente, aumentaria o número de partículas virais suspensas ou aerosóis.

AUGE et alii (1977), para imunizar os bovinos com va cinas inativadas que contēm adjuvante oleoso, sugerem o seguinte es quema: aplicação de uma dose a cada seis meses, em animais jovens - até dois anos de idade e, com intervalos de um ano, as vacinações seguintes.

BEKKUM (1977) ressalta que a resposta imunitāria dos bovinos, quando vacinados, pode ser afetada pelos fatores: idade, componente genético, saūde e nutrição.

O CENTRO PANAMERICANO DE FEBRE AFTOSA (1978) demonstra, experimentalmente, que, ao utilizar vacinas oleosas em bovinos, a mêdia de anticorpos tende a aumentar em relação à idade dos animais e ao nümero de vacinações, independentemente do tipo de vírus. Comprova, ainda, que diminui a variação dos níveis de anticorpos com o aumento da idade dos animais.

KHUKHOROV et alii (1978) investigaram a duração da imunidade adquirida através do colostro, em terneiros nascidos de va cas convalescentes de febre aftosa. Chegaram, pois, às seguintes con clusões: 24 horas apōs a ingestão do colostro o indice de soro pro- 
teção (ISP) era $\log _{2} 7$, até os 5 dias subsequentes; aos 45 dias de lactação, $\log _{2} 6,7$; aos 60,90 e 120 dias, de $\log _{2} 5,1, \log _{2} 2,4$ e $\log _{2} 1,2$, respectivamente. Aos 135 dias, não se detectaram anticorpos neutralizantes.

Face à diminuição dos anticorpos neutralizantes e con siderando a sua eliminação, depreende-se a necessidade da vacinação dos animais a partir de 120 dias de idade.

O CENTRO PANAMERICANO DE, FEBRE AFTOSA (1979) assinala que as perdas mais importantes em gado de corte são ocasionadas pela diminuição do peso. Isto resulta num atraso de até 100 dias na entrega do produto final.

A recuperação do peso destes animais implicaria, por tanto, em gastos desnecessärios. Eles seriam, então, evitados caso os animais tivessem adquirido, através do uso de vacinação, um índi ce de imunização satisfatório.

OBIAGA et alii (1979) afirmam que, nas áreas de alta densidade populacional, os bovinos destinados à engorda são responsāveis por um permanente afluxo de fontes de infecção. Nesse caso,o aparecimento de focos mais intensos ocorre, particularmente, quando aqueles estão concentrados com animais já na fase final de engorda. ASTUDILLO et alii (1980) observaram que a frequência de rebanhos afetados por febre aftosa, em municípios do Estado do Rio Grande do Sul, nos meses de maio e junho, alcançou níveis epidê micos, superando o esperado para aquele período. Demonstraram que, nesse Estado, a região de maior risco com ocorrência de febre afto- 
sa $\vec{e}$ a de maior densidade animal e de maior trânsito de gado.

O CENTRO PANAMERICANO DE FEBRE AFTOSA (1980), estudando a definição dos ecosistemas de febre aftosa no Estado do Rio Grande do Sul, analisou três fatores: densidade bovina, rebanhos afetados e movimentação de animais. Este último foi um dos mais importantes na elucidação do problema.

GOMES et alii (1980) descrevem a seguinte experiência: 30 vacas foram vacinadas 3 vezes - vacina antiaftosa - com ad juvante oleoso, num intervalo de 6 meses. Esses animais expostos ao vírus aftoso, 13 meses depois da última vacinação, apenas um apresentou aftosa generalizada. Face a essas observações, portanto, pode-se confirmar que os níveis de anticorpos elevados indicam uma imu nidade eficaz.

SUTMÖLLER et aZii (1980) examinaram 532 soros de bovinos vacinados mediante a prova de microneutralização adotada como rotina pelo Centro Panamericano de Febre Aftosa, tendo sido calcula da a expectativa percentual de proteção (EPP) para os títulos de so roneutralização, sendo proposta esta medida como indicador do estado de imunidade dos animais.

O CENTRO PANAMERICANO DE FEBRE AFTOSA (1981) relata que o procedimento utilizado no Rio Grande do Sul, quanto ao contro le de trânsito dos animais, resume-se em apresentação do certificado de vacinação. Aponta que a natureza do terreno, facilitandoo con tato dos animais entre rebanhos município a município, dificulta sen 
sivelmente o controle de trânsito que tem por finalidade evitar a difusão da febre aftosa.

$$
\text { ASTUDILLO (1982) apresenta um estudo em que a taxa }
$$

de ataque, nos bovinos menores de 2 anos, oscilou entre $16 \%$ e $27 \%$; variou, no entanto, nos animais maiores de 2 anos entre $8 \%$ a $20 \%$. Levando em consideração o tempo pós-vacinação $(30,60,90$ e 120 dias) as taxas de ataque foram de $19 \%, 24 \%, 34 \%$ e $23 \%$, respectivamente. Isto evidencia a impcrtância da vacinação para aumento da ta xa de anticorpos.

O CENTRO PANAMERICANO DE FEBRE AFTOSA (1982) recomen da intensificar o adestramento de pessoal para a'investigação epidemiológica dos focos de febre aftosa, a fim de melhorar as estimativas de ataque correspondentes, assim como manter atualizados os re gistros da população pecuária e os de vacinação, com o propósito de estimar indicadores para avaliação oportuna dos programas de imunização antiaftosa. 


\section{MATERIAL E METODOS}

\section{1 - Material}

Os dados estatísticos foram extraídos das publicações da Unidade de Defesa Sanitäria Animal da Secretaria de Agricultura do Rio Grande do Sul, pertencentes ao arquivo do Centro Panamericano de Febre Aftosa. Abrangem o período de 1973 a 1980.

Deve ser ressaltado que ocorreram períodos de alta e baixa frequência de focos nesse estudo, aspecto importante para tal comparação.

As informações obtidas referem-se:

a) A população de animais bovinos de todo o Estado. Foram consideradas em cada mês as faixas etärias: menores de 4 meses, de 4 meses a 1 ano, de 1 a 2 anos e maiores de 2 anos. 
Tal divisão faz-se necessāria, pois a imunidade é dis tinta, mesmo após a vacinação, nas 4 classes.

b) A movimentação mensal de animais, com destino ao abate (comercialização.

Este transporte de animais, município a município, conforme mostram os cartogramas do Apêndice, é procedida por estradas, com o gado a pé, quando a distância apresenta um pequeno percurso e através rodovia ou ferrovia, de acordo com a viabilidade existente.

c) Ao número de focos de febre aftosa, confirmados, mensalmente.

d) A niveis mensais de imunização que foram estimados a partir de informações do item a. Para tanto foram levadas em consideração as quatro classes, com seus respectivos coeficientes, conforme discriminação a seguir.

\section{2 - Métodos}

\subsection{1 - Bezerros menores de 4 meses $\left(n_{1}\right)$}

Atribuiu-se um coeficiente 0,6, tendo em conta que os bezerros mantêm imunidade passiva, adquirida pelo colostro. Essa imunidade tem um valor máximo nos primeiros dias de vida e diminui rapidamente até o 40 mês. Nesta época ela è mínima. 
3.2.2 - Bezerros maiores de 4 meses e menores de 1 ano $\left(n_{2}\right)$

Conferiu-se um coeficiente 0,2. A imunidade dos animais é mínima, apesar de já efetuadas uma ou duas vacinações.

\subsection{3 - Bovinos jovens $\left(n_{3}\right)$}

Animais entre 1 e 2 anos. Coeficiente igual a 0,8. As repetidas vacinaçôes aproximam a imunidade dos jovens à dos adultos.

\section{2 .4 - Bovinos adultos $\left(n_{4}\right)$}

Maiores de 2 anos. Atingem o máximo de imunidade, com coeficiente de valor 1 .

\section{3 - Indices Mensais}

Com exceção dos bezerros menores de 4 meses (que não são vacinados) atribuiu-se aos demais um indice de valor 1 , aos trin ta dias após vacinação. Este diminui para 0,95, 0,90 e 0,80 aos 60, 90 e 120 dias, respectivamente, após a vacinação. Isto resulta de um período de vacinação com intervalos de quatro meses (janeiro, maio e setembro). Ocorre tal fato visto ser, de curta duração, o es tímulo das vacinas com hidróxido de alumínio.

Os animais, nos meses de vacinação, apresentam os me nores índices de soro proteção (ISP), elevando-se aos 30 dias após, para em seguida decrescer. 
O nível de imunização è estimado através da seguinte fórmula:

$$
N I \%=100 \cdot\left[\frac{0,6 n_{1}+\operatorname{IM}\left(0,2 n_{2}+0,8 n_{3}+n_{4}\right)}{n_{1}+n_{2}+n_{3}+n_{4}}\right],
$$

segundo OBIAGA (1981) $\stackrel{1 /}{ }$, sendo que:

$$
\begin{aligned}
& \mathrm{NI}=\text { nível de imunização estimado; } \\
& \mathrm{IM}=\text { índice mensal; } \\
& \mathrm{n}_{1}, \mathrm{n}_{2}, \mathrm{n}_{3} \text { e } \mathrm{n}_{4}=\text { número de animais nas } 4 \text { faixas etärias. } \\
& \quad 0 \text { procedimento de classificar o mês como epidêmico }
\end{aligned}
$$

ou alta frequência, e endêmico ou baixa frequência, consistiu na observação ao longo do período estudado, dos focos confirmados da doença.

Considerou-se, então, o valor mediano e adotou-se o critério de mês epidêmico ou alta frequência - aquele cujo número de focos confirmados foi maior que o valor determinado. Da mesma forma, foi considerado como mês endêmico ou baixa frequência, aquele em que o número de focos foi menor que o valor mediano.

\section{4 - Anālise Estatística}

\subsection{1 - Coeficientes de correlação e de determinação}

Foram aqui adotados os procedimentos descritos em SNE DECOR (1956)

$$
\text { Assim, para: }
$$

1/ Comunicação pessoal. (CPFA-RJ) 


$$
\begin{aligned}
y & =\text { número de focos confirmados; } \\
x_{1} & =\text { nümero de animais em movimento; } \\
x_{2} & =\text { nível de imunização estimado; }
\end{aligned}
$$

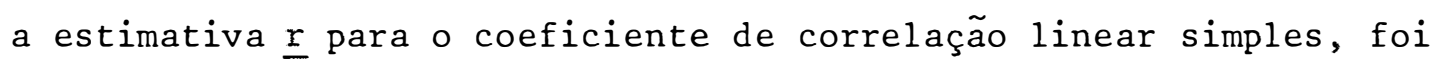
obtida de:

$$
r=\frac{\sum_{x y}-\frac{\sum x}{N} \cdot \sum y}{\sqrt{\left(\Sigma x^{2}-\frac{(\Sigma x)^{2}}{N}\right)\left(\Sigma y^{2}-\frac{(\Sigma y)^{2}}{N}\right)}}
$$

De modo anālogo, o coeficiente de correlação mültipla foi determinado através:

$$
R=\sqrt{\frac{r_{y x_{1}}^{2}+r_{y x_{2}}^{2}-2 r_{y x_{1}} r_{y x_{2}} r_{x_{1} x_{2}}}{1-r_{x_{1} x_{2}}^{2}}}
$$

E, para os coeficientes de determinação:

$$
\mathrm{R}^{2}=\frac{\mathrm{SQ} \text { Regressão }}{\text { SQ Total }}=\frac{\sum(\hat{\mathrm{y}}-\overline{\mathrm{y}})^{2}}{\sum(\mathrm{y}-\overline{\mathrm{y}})^{2}}
$$




\subsection{2 - Equações de regressão linear simples e mūltipla}

Na obtenção das equações de regressão linear simples, do nümero de focos confirmados sobre o número de animais movimentados e, posteriormente, do número de focos confirmados sobre o nível de imunização estimado, foram adotados os procedimentos de BRADFORD HILL (1956).

$$
\begin{aligned}
& \text { Desse modo, tomou-se o modelo linear: } \\
& \qquad y=X \theta+e^{-}, \text {em que e } \cap N\left(0, \sigma^{2}\right),
\end{aligned}
$$

onde :

$$
\begin{aligned}
& \mathrm{y}=\text { vetor das observações; } \\
& \mathrm{X}=\text { matriz conhecida dos coeficientes dos parâmetros; } \\
& \theta=\text { vetor dos parâmetros } \alpha \text { e } B \text {, desconhecidos; } \\
& \mathrm{e}=\text { vetor dos erros aleatórios; }
\end{aligned}
$$

cuja solução de minimos quadrados forneceu os estimadores a para o coeficiente linear $\underline{\alpha}$, e $\underline{b}$ para o coeficiente de regressão linear $\underline{\beta}$. Assim, do desenvolvimento do modelo obteve-se:

$$
y_{i}=a+b x_{i} \text {, }
$$

onde :

$$
\begin{aligned}
\mathrm{y}_{\mathrm{i}} & =\text { nümero de focos confirmados; } \\
\mathrm{a} & =\text { coeficiente linear }
\end{aligned}
$$




$$
\begin{aligned}
b & =\text { coeficiente de regressão linear; } \\
x_{1 i} & =\text { número de animais em movimento; } \\
x_{2 i} & =\text { nível de imunização estimado. }
\end{aligned}
$$

Analogamente, para as regressões mūltiplas, consideraram-se duas variāveis independentes $X_{1}$ e $X_{2}$, e o modelo seria:

$$
y_{i}=a+b_{1} x_{1 i}+b_{2} x_{2 i}+e_{i}
$$

onde:

$$
\left.\begin{array}{rl}
y_{i} & =\text { valores observados; } \\
b_{j} & =\text { parâmetros } \\
x_{j i} & =\text { coeficientes }
\end{array}\right\} \text { onde } j=1 \text { e } 2 ;
$$

e admite-se que $e_{i} \cap N\left(0, \sigma^{2}\right)$.

\section{Assim:}

$$
\begin{aligned}
& \mathrm{y}_{i}=\text { número de focos confirmados; } \\
& \mathrm{b}_{1} \text { e } \mathrm{b}_{2}=\text { parâmetros; } \\
& \mathrm{x}_{1 i}=\text { número de animais em movimento; } \\
& \mathrm{x}_{2 i}=\text { nível de imunização estimado. }
\end{aligned}
$$




\subsection{3 - Anālise da variāncia}

Quanto aos dados referentes ao nümero de focos confirmados da febre aftosa, no período de 1973 a 1980, nos diversos me ses, foi procedida análise da variância, com delineamento em blocos casualizados, aplicando-se o teste $F$ para verificar diferenças quan to a mëdias de focos nos anos e meses. Quando significativo o valor de F utilizou-se o teste de Duncan, adotando-se para tal o nível de significância de $5 \%$ de probabilidade $(P<0,05)$, segundo PIMENTEL GO MES (1978).

Por conseguinte, o modelo matemático corresponde a:

$$
y_{i j}=m+t_{i}+b_{j}+e_{i j}
$$

considerando-se: $\sum_{i} t_{i}=0 ; \sum_{j} b_{j}=0$, e com

$y_{i j}=$ focos confirmados;

$\mathrm{m}=$ média geral;

$t_{i}=$ efeito de tratamentos (anos);

$\mathrm{b}_{j}=$ efeito de blocos (meses);

$e_{i j}=$ erro ou resíduo $N\left(0, \sigma^{2}\right)$, aleatório.

o esquema da anālise de variância foi o seguinte:

\begin{tabular}{lc}
\hline Causas da Variação & Graus de Liberdade \\
\hline Tratamentos (anos) & I - I \\
Blocos (meses) & $\mathrm{J}-1$ \\
Resíduo & $(\mathrm{I}-\mathrm{I})(\mathrm{J}-\mathrm{I})$ \\
\hline TOTAL & IJ -1 \\
\hline
\end{tabular}


Quanto ao teste de Duncan, determinaram-se diferenças mínimas significativas, de acordo com o número de mëdias abrangidas para comparação, segundo a expressão:

$$
\mathrm{D}=2 \cdot \frac{\mathrm{s}}{\sqrt{\mathrm{r}}},
$$

onde $\underline{r} \bar{e}$ o nümero de repetições, $\underline{s}$ è o desvio padrão, e $\underline{z} \vec{e}$ tirado das tabelas, para o nümero de médias ordenadas abrangidas pelo contraste comparado e o número de graus de liberdade do resíduo. 
24.

\section{RESULTADOS E DISCUSSÃO}

\section{1 - Anālises de Regressão e de Correlação}

Para fins das anālises propostas, são apresentadas as Tabelas de 1 a 11. Elas resumem, no período estudado, os dados obti dos quanto ao número de animais em movimento, nível de imunização es timado e focos confirmados da doença. 
Tabela 1 - Movimentação de animais, nível de imunização estimado e nümero de focos confirmados. Rio Grande do Sul, 1973.

\begin{tabular}{lccc}
\hline MESES & $\begin{array}{c}\text { Número de } \\
\text { nimais en } \\
\text { movimento } \\
\left(\mathrm{x}_{1}\right)\end{array}$ & $\begin{array}{c}\text { Nível de } \\
\text { imunização } \\
\text { estimado } \\
\left(\mathrm{x}_{2}\right)\end{array}$ & $\begin{array}{c}\text { Focos } \\
\text { confirmados } \\
(\mathrm{y})\end{array}$ \\
\hline Janeiro & 88.134 & 71,2 & 200 \\
Fevereiro & 94.524 & 86,9 & 197 \\
Março & 151.779 & 83,0 & 403 \\
Abril & 205.393 & 76,7 & 469 \\
Maio & 252.336 & 67,3 & 740 \\
Junho & 172.196 & 83,2 & 556 \\
Julho & 76.677 & 82,1 & 331 \\
Agosto & 58.713 & 78,9 & 124 \\
Setembro & 44.509 & 71,3 & 102 \\
Outubro & 49.680 & 88,2 & 108 \\
Novembro & 68.445 & 83,7 & 102 \\
Dezembro & 88.241 & 79,3 & 78 \\
\hline
\end{tabular}

$$
x_{1} \text { e } y:
$$

$y=-54,39+0,00301 x_{1}$

$$
\begin{aligned}
& r_{x_{1}, y}=0,9347 * * \\
& r_{x_{1}}^{2}, y=0,8737 \\
& r_{x_{1}, x_{2}}=-0,3653^{n s} \\
& r_{x_{1}, x_{2}}^{2}=0,1334
\end{aligned}
$$

$x_{1}, x_{2}$ e $y:$

$y=-89,17+0,0030 x_{1}+0,42 x_{2}$

$r_{x_{2}, y}=-0,3304^{n s} ;$
$r_{x_{2}, y}^{2^{n}}=0,1092$

$\mathrm{R}_{\mathrm{x}_{1} \mathrm{x}_{2}, \mathrm{y}}=0,9348 * *$ $\mathrm{R}_{\mathrm{x}_{1} \mathrm{x}_{2}, \mathrm{y}}^{2_{1} \mathrm{x}_{2}, \mathrm{y}}=0,8739$

Foram significativos os valores de $\mathrm{r}_{\mathrm{x}_{1}, \mathrm{y}}$ e $\mathrm{R}_{\mathrm{x}_{1} \mathrm{x}_{2}, \mathrm{y}}$, ao nível de $1 \%$ de probabilidade $(\mathrm{P}<0,01)$. 
Tabela 2 - Movimentação de animais, nível de imunização estimado e número de focos confirmados. Rio Grande do Sul, 1974.

\begin{tabular}{lccc}
\hline MESES & $\begin{array}{c}\text { Número de } \\
\text { animais en } \\
\text { movimento } \\
\left(\text { (i) }_{1}\right)\end{array}$ & $\begin{array}{c}\text { Nível de } \\
\text { imunização } \\
\text { estimado } \\
\left(x_{2}\right)\end{array}$ & $\begin{array}{c}\text { Focos } \\
\text { confirmados } \\
(y)\end{array}$ \\
\hline Janeiro & 75.662 & 70,8 & 62 \\
Fevereiro & 98.554 & 86,5 & 46 \\
Março & 161.740 & 81,5 & 146 \\
Abril & 210.538 & 76,5 & 253 \\
Maio & 217.392 & 67,3 & 211 \\
Junho & 140.371 & 84,9 & 74 \\
Julho & 68.977 & 81,7 & 39 \\
Agosto & 47.659 & 78,4 & 32 \\
Setembro & 37.052 & 70,7 & 23 \\
Outubro & 51.346 & 87,9 & 15 \\
Novembro & 50.126 & 83,7 & 23 \\
Dezembro & 71.052 & 79,5 & 28 \\
\hline
\end{tabular}

$$
\begin{aligned}
& x_{1} \text { e } y: \quad x_{1}, x_{2} \text { e } y: \\
& y=-42,23+0,00119 x_{1} \quad y=122,28+0,00113 x_{1}-2,01 x_{2} \\
& \begin{array}{lll}
r_{x_{1}, y}=0,9513^{*} & ; & r_{x_{2}, y}=-0,4145^{n s} \\
r_{x_{1}, y}^{2}=0,9051 & ; & r_{x_{2}, y}^{2}=0,1718^{n s}
\end{array} ;
\end{aligned}
$$

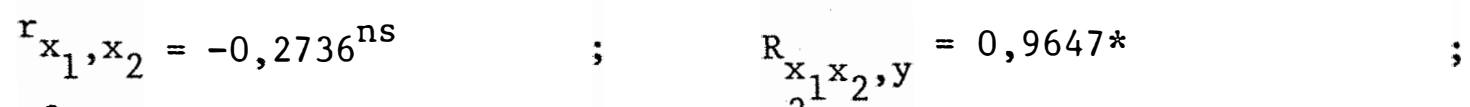

$$
\begin{aligned}
& \mathrm{r}_{\mathrm{x}_{1}, \mathrm{x}_{2}}^{2}=0,0749 \quad ; \quad \mathrm{R}_{\mathrm{x}_{1} \mathrm{x}_{2}, \mathrm{y}}^{2}=0,9308 \\
& \text { Os valores de } \mathrm{r}_{\mathrm{x}_{1}, \mathrm{y}} \text { e } \mathrm{R}_{\mathrm{x}_{1} \mathrm{x}_{2}, \mathrm{y}} \text { foram significativos ao }
\end{aligned}
$$

nível de $5 \%$ de probabilidade $(\mathrm{P}<0,05)$. 
Tabela 3 - Movimentação de animais, nível de imunização estimado e nümero de focos confirmados. Rio Grande do Sul, 1975.

\begin{tabular}{lccc}
\hline MESES & $\begin{array}{c}\text { Nümero de } \\
\text { animais em } \\
\text { movimento } \\
\left(\mathrm{x}_{1}\right)\end{array}$ & $\begin{array}{c}\text { Nível de } \\
\text { imunização } \\
\text { estimado } \\
\left(\mathrm{x}_{2}\right)\end{array}$ & $\begin{array}{c}\text { Focos } \\
\text { confirmados } \\
(y)\end{array}$ \\
\hline Janeiro & 77.339 & 71,2 & 33 \\
Fevereiro & 94.652 & 86,9 & 25 \\
Março & 133.311 & 81,9 & 30 \\
Abril & 201.343 & 76,8 & 74 \\
Maio & 204.947 & 67,5 & 100 \\
Junho & 124.449 & 85,1 & 154 \\
Julho & 71.486 & 81,9 & 206 \\
Agosto & 53.966 & 78,5 & 127 \\
Setembro & 46.706 & 70,8 & 108 \\
Outubro & 66.799 & 85,3 & 101 \\
Novembro & 78.476 & 83,6 & 69 \\
Dezembro & 86.467 & 79,4 & 79 \\
& & & \\
\hline
\end{tabular}

$$
\begin{aligned}
& x_{1} \text { e y: } \quad x_{1}, x_{2} \text { e } y: \\
& y=109,50-0,00017 x_{1} \quad y=101,79-0,00016 x_{1}+0,09 x_{2} \\
& r_{x_{1}, y}=0,1667^{n s} \quad ; \quad r_{x_{2}, y}=0,0548^{n s} ; \\
& \mathrm{r}_{\mathrm{x}_{1}, \mathrm{y}}^{2^{1}}=0,0278 \quad ; \quad \mathrm{r}_{\mathrm{x}_{2}, \mathrm{y}}^{2^{2}}=0,0030 \text {; } \\
& \begin{array}{lll}
r_{x_{1}, x_{2}}=-0,2672^{n s} & ; & R_{x_{1} x_{2}, y}=0,1670^{n s} \\
r_{x_{1}}^{2} x_{2}=0,0714 & ; & R_{x_{1} x_{2}, y}^{2}=0,0279
\end{array} \text {; }
\end{aligned}
$$

Os valores dos coeficientes não foram significativos. 
Tabela 4 - Movimentação de animais, nível de imunização estimado e nümero de focos confirmados. Rio. Grande do Sul, 1976.

\begin{tabular}{lccc}
\hline MESES & $\begin{array}{c}\text { Nümero de } \\
\text { animais em } \\
\text { movimento } \\
\left(\mathrm{x}_{1}\right)\end{array}$ & $\begin{array}{c}\text { Nível de } \\
\text { imunizaçäo } \\
\text { estimado } \\
\left(\mathrm{x}_{2}\right)\end{array}$ & $\begin{array}{c}\text { Focos } \\
\text { confirmados } \\
(\mathrm{y})\end{array}$ \\
\hline Janeiro & 92.888 & 71,1 & 79 \\
Fevereiro & 126.176 & 86,9 & 92 \\
Março & 186.697 & 81,9 & 265 \\
AbriI & 222.631 & 76,9 & 519 \\
Maio & 225.888 & 67,6 & 768 \\
Junho & 171.541 & 85,2 & 1.122 \\
JuIho & 91.051 & 81,9 & 1.110 \\
Agosto & 63.742 & 78,5 & 488 \\
Setembro & 54.573 & 70,8 & 207 \\
Outubro & 65.999 & 87,6 & 91 \\
Novembro & 71.611 & 83,0 & 211 \\
Dezembro & 84.863 & 78,5 & 216 \\
\hline
\end{tabular}

$$
\begin{aligned}
& x_{1} \text { e } y: \quad x_{1}, x_{2} \text { e } y: \\
& y=143,04+0,00237 x_{1} \quad y=191,01+0,00244 x_{1}+4,11 x_{2}
\end{aligned}
$$

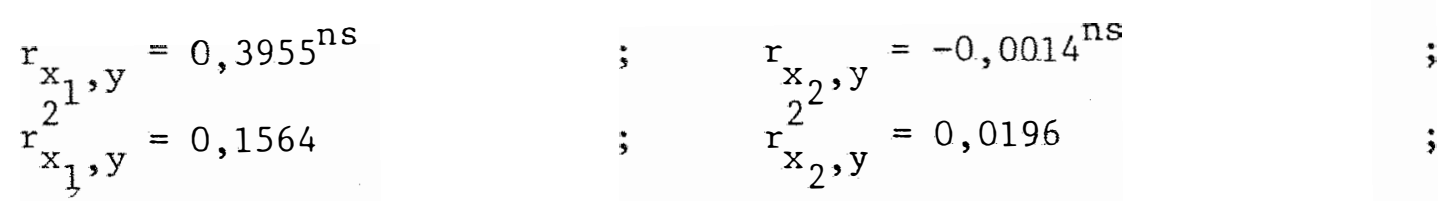

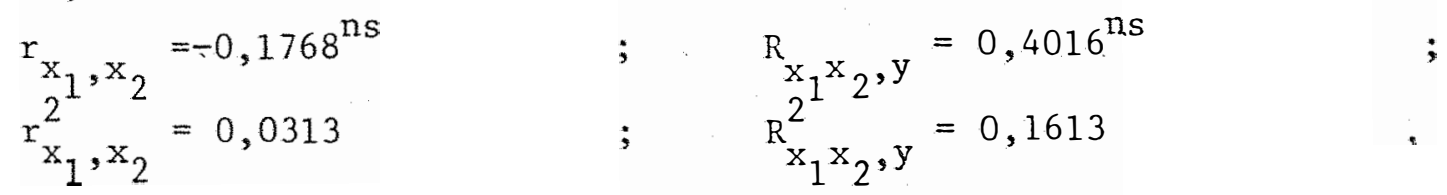

Os valores dos coeficientes não foram significativos. 
29.

Tabela 5 - Movimentação de animais, nível de imunização estimado e nümero de focos confirmados. Rio. Grande do Sul, 1977.

\begin{tabular}{lccc}
\hline MESES & $\begin{array}{c}\text { Nümero de } \\
\text { animais em } \\
\text { movimento } \\
\left(\mathrm{x}_{1}\right)\end{array}$ & $\begin{array}{c}\text { Nível de } \\
\text { imunização } \\
\text { estimado } \\
\left(\mathrm{x}_{2}\right)\end{array}$ & $\begin{array}{c}\text { Eocos } \\
\text { confirmados } \\
(\mathrm{y})\end{array}$ \\
\hline Janeiro & 97.790 & 69,9 & 348 \\
Fevereiro & 101.286 & 86,3 & 285 \\
Março & 184.063 & 81,9 & 243 \\
Abril & 247.397 & 77,4 & 107 \\
Maio & 248.389 & 68,7 & 141 \\
Junho & 147.959 & 85,4 & 122 \\
Julho & 78.139 & 80,8 & 46 \\
Agosto & 77.139 & 77,8 & 29 \\
Setembro & 77.085 & 70,6 & 52 \\
Outubro & 92.134 & 88,9 & 46 \\
Novembro & 104.661 & 84,1 & 24 \\
Dezembro & 111.552 & 79,3 & - \\
\hline
\end{tabular}

$$
\begin{aligned}
& x_{1} \text { e } y: \quad x_{1}, x_{2} \text { e } y: \\
& y=75,49+0,00035 x_{1} \quad y=268,55+0,00029 x_{1}-2,33 x_{2} \\
& \begin{array}{lll}
r_{x_{1}, y}=0,1941^{n s} & ; & r_{x_{2}, y}=-0,1779^{n s} \\
r_{x_{1}, y}=0,0377 & ; & r_{x_{2}, y}^{2}=0,0316
\end{array} ; \\
& \begin{array}{lll}
\mathrm{r}_{\mathrm{x}_{1}, \mathrm{x}_{2}}=-0,2479^{\mathrm{ns}} & ; & \mathrm{R}_{\mathrm{x}_{1} \mathrm{x}_{2}, \mathrm{y}}=0,2359^{\mathrm{ns}} \\
\mathrm{r}_{\mathrm{x}_{1}, \mathrm{x}_{2}=0,0615} & ; & \mathrm{R}_{\mathrm{x}_{1} \mathrm{x}_{2}, \mathrm{y}}^{2^{2}}=0,0556
\end{array} \text {; }
\end{aligned}
$$


Tabela 6 - Movimentação de animais, nível de ımunızação estimado e nümero de focos confirmados. Rio Grande do Sul, 1978.

\begin{tabular}{|c|c|c|c|}
\hline MESES & $\begin{array}{l}\text { Numero de } \\
\text { anima:s em } \\
\text { movir ento } \\
\left(x_{1}\right)\end{array}$ & $\begin{array}{c}\text { Nível de } \\
\text { Imunizaçao } \\
\text { estimado } \\
\left(\mathrm{x}_{2}\right)\end{array}$ & $\begin{array}{c}\text { Focos } \\
\text { confirmados } \\
\text { (y) }\end{array}$ \\
\hline Janeiro & 127.072 & 70,3 & 56 \\
\hline Eevereiro & 101. 028 & 86,6 & 50 \\
\hline Março & 159.819 & 81,9 & 61 \\
\hline Abril & 204.622 & 77,2 & 147 \\
\hline Maio & 213.651 & 68,3 & 78 \\
\hline Junho & 107.715 & 84,6 & 44 \\
\hline Julho & 64.494 & 81,6 & 11 \\
\hline Agosto & 58.153 & 78,5 & 12 \\
\hline Setembro & 58.094 & 71,1 & 35 \\
\hline Outubro & 71.812 & 89,4 & 78 \\
\hline Novembro & 78.021 & 84,4 & 28 \\
\hline Dezembro & 99.006 & 79,4 & 8 \\
\hline
\end{tabular}

$$
\begin{aligned}
& x_{1} \text { e y: } \quad x_{1}, x_{2} \in y: \\
& y=-8,98+0,00053 x_{1} \quad y=-117,74+0,00059 x_{1}+1,27 x_{2}
\end{aligned}
$$

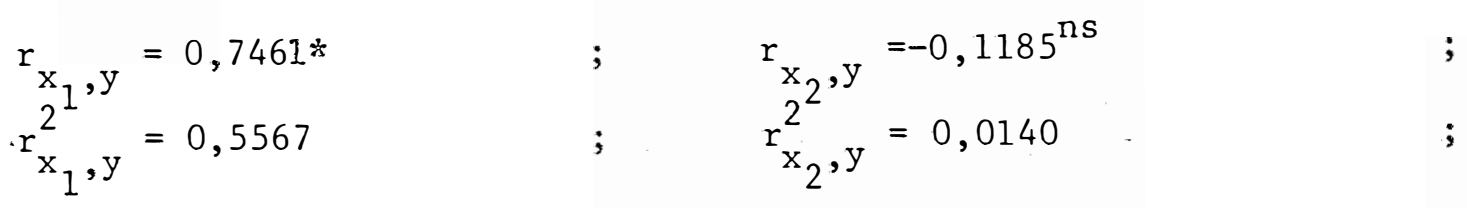

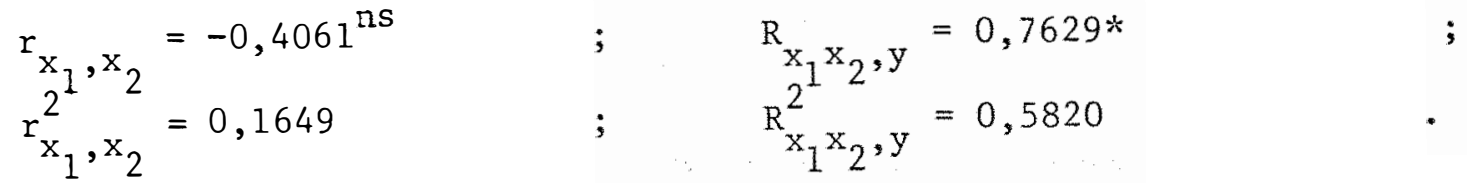

$$
\begin{aligned}
& \text { Os valores de } \mathrm{r}_{\mathrm{x}_{1}, \mathrm{y}} \text { e } \mathrm{R}_{\mathrm{x}_{1} \mathrm{x}_{2}, \mathrm{y}} \text { foram significativos ao }
\end{aligned}
$$
nível de $5 \%$ de probabilidade $(P<0,05)$. 
31.

Tabela 7 - Movimentação de animais, nível de imunização estimado e nümero de focos confirmados. Rio Grande do Sul, 1979.

\begin{tabular}{lccc}
\hline MESES & $\begin{array}{c}\text { Nümero de } \\
\text { animais em } \\
\text { movimento } \\
\left(x_{1}\right)\end{array}$ & $\begin{array}{c}\text { Nivel de } \\
\text { imunização } \\
\text { estimado } \\
\left(x_{2}\right)\end{array}$ & $\begin{array}{c}\text { Focos } \\
\text { confirmados } \\
(y)\end{array}$ \\
\hline Janeiro & 134.844 & 70,3 & 18 \\
Fevereiro & 114.335 & 86,3 & 11 \\
Março & 122.869 & 81,7 & 8 \\
Abril & 156.314 & 77,0 & 19 \\
Maio & 164.892 & 68,1 & 29 \\
Junho & 85.862 & 84,3 & 26 \\
Julho & 54.873 & 81,3 & 3 \\
Agosto & 48.465 & 78,3 & 10 \\
Setembro & 56.319 & 71,0 & 50 \\
Outubro & 79.680 & 89,2 & 44 \\
Novembro & 83.796 & 84,2 & 149 \\
Dezembro & 86.371 & 79,2 & \\
\hline
\end{tabular}

$$
\begin{aligned}
& x_{1} \in y: \quad x_{1}, x_{2} \in y: \\
& y=40,04+0,00008 x_{1} \quad y=-17,60-0,00004 x_{1}+0,675 x_{2} \\
& r_{x_{1}, y}=0,0784^{n s} \quad ; \quad r_{x_{2}, y}=0,1276^{n s} \text {; } \\
& r_{x_{1}, y}^{2^{1}}=0,0061 \quad ; \quad r_{x_{2}, y}^{2^{2}, y}=0,0162 ; \\
& \begin{array}{lll}
\mathrm{r}_{\mathrm{x}_{1}, \mathrm{x}_{2}}=-0,3620^{\mathrm{ns}} & ; & \mathrm{R}_{\mathrm{x}_{1} \mathrm{x}_{2}, \mathrm{y}}=0,1322^{\mathrm{ns}} \\
\mathrm{r}_{\mathrm{x}_{1}, \mathrm{x}_{2}=0,1310} & ; & \mathrm{R}_{\mathrm{x}_{1} \mathrm{x}_{2}, \mathrm{y}}^{2}=0,0174
\end{array}
\end{aligned}
$$

Os valores dos coeficientes não foram significativos. 
Tabela 8 - Movimentação de animais, nível de imunização estimado e nümero de focos confirmados. Rio Grande do Sul, 1980.

\begin{tabular}{lccc}
\hline MESES & $\begin{array}{c}\text { Nümero de } \\
\text { animais em } \\
\text { movimento } \\
\left(\mathrm{x}_{1}\right)\end{array}$ & $\begin{array}{c}\text { Nivel de } \\
\text { imunização } \\
\text { estimado } \\
\left(\mathrm{x}_{2}\right)\end{array}$ & $\begin{array}{c}\text { Focos } \\
\text { confirmados } \\
(\mathrm{y})\end{array}$ \\
\hline Janeiro & 111.570 & 70,1 & 34 \\
Fevereiro & 100.809 & 85,9 & 21 \\
Março & 121.414 & 81,3 & 28 \\
Abril & 161.138 & 76,7 & 104 \\
Maio & 167.097 & 68,0 & 131 \\
Junho & 79.531 & 84,3 & 97 \\
Julho & 58.691 & 81,0 & 48 \\
Agosto & 43.754 & 77,7 & 43 \\
Setembro & 50.383 & 70,5 & 29 \\
Outubro & 61.740 & 88,3 & 33 \\
Novembro & 66.222 & 83,8 & 58 \\
Dezembro & 84.611 & 79,2 & 35 \\
& & &
\end{tabular}

$x_{1}$ e $y:$

$y=7,25+0,00052 x_{1}$

$r_{x_{1}, y}=0,5986 *$
$r_{x_{1}, y}=0,3583$

$r_{x_{1}, x_{2}}=-0,38$
$r_{x_{1}, x_{2}}^{2}=0,1501$

Os valores de $\mathrm{r}_{\mathrm{x}_{1}}, \mathrm{y}$ $x_{1}, x_{2}$ e $y:$

$y=51,24-0,52 x_{2}$

$\quad \mathrm{r}_{\mathrm{x}_{2}, \mathrm{y}}=-0,3131^{\mathrm{ns}}$

; $\quad \mathrm{r}_{\mathrm{x}_{2}, \mathrm{y}}^{2}=0,0980$

; $\quad \mathrm{R}_{\mathrm{x}_{1} \mathrm{x}_{2}, \mathrm{y}}=0,6050 *$

$; \quad \mathrm{R}_{\mathrm{x}_{1} \mathrm{x}_{2}, \mathrm{y}}^{2}=0,3661$

e $R_{x_{1} x_{2}, y}$ foram significativos ao nível de $5 \%$ de probabilidade $(P<0,05)$. 
Tabela 9 - Mëdias dos meses do período quanto à movimentação de animais, nível de imunização estimado e número de focos con firmados. Rio Grande do Sul, 1973-1980.

\begin{tabular}{lccc}
\hline MESES & $\begin{array}{c}\text { Numero de } \\
\text { animais em } \\
\text { movimento } \\
\left(\mathrm{x}_{1}\right)\end{array}$ & $\begin{array}{c}\text { Nível de } \\
\text { imunização } \\
\text { estimado } \\
\left(\mathrm{x}_{2}\right)\end{array}$ & $\begin{array}{c}\text { Focos } \\
\text { confirmados } \\
(\mathrm{y})\end{array}$ \\
\hline Janeiro & 100.662 & 70,6 & 104 \\
Fevereiro & 103.920 & 86,5 & 91 \\
Março & 152.712 & 81,9 & 148 \\
Abril & 201.172 & 76,9 & 212 \\
Maio & 211.824 & 67,9 & 275 \\
Junho & 128.703 & 84,6 & 274 \\
Julho & 70.549 & 81,5 & 226 \\
Agosto & 56.449 & 78,3 & 107 \\
Setembro & 53.090 & 70,9 & 71 \\
Outubro & 67.399 & 88,1 & 65 \\
Novembro & 75.170 & 83,8 & 68 \\
Dezembro & 88.520 & 79,2 & 77 \\
\hline
\end{tabular}

$x_{1}$ e $y:$

$y=30,38+0,00103$

$r_{x_{1}, y}=0,6850 *$
$r_{x_{1}, y}^{2}=0,4693$

$r_{x_{1}, x_{2}}=-0,3127^{n s}$
$r_{x_{1}, x_{2}}=0,0978$ $x_{1}, x_{2}$ e $y:$

$y=17,47+0,15 x_{2}$

; $\quad r_{x_{2}, y}=-0,2029^{\text {ns }}$

$; \quad x_{x_{2}, y}^{x_{2}, y}=0,0412$

$; \quad \mathrm{R}_{\mathrm{x}_{1} \mathrm{x}_{2}, \mathrm{y}}=0,6851 *$
$\mathrm{R}_{\mathrm{x}_{1} \mathrm{x}_{2}, \mathrm{y}}=0,4694$
;

;

;

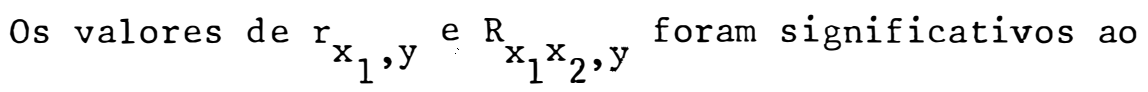
nível de $5 \%$ de probabilidade $(\mathrm{P}<0,05)$. 


$$
34 .
$$

Tabela 10 - Movimentação de animais, nível de imunização estimado e nümero de focos confirmados, nos meses do período, considerados de baixa frequência. Rio Grande do Sul, 1973-1980 .

\begin{tabular}{|c|c|c|c|c|}
\hline $\begin{array}{c}\text { ANO } \\
=\end{array}$ & MESES & $\begin{array}{l}\text { Número de } \\
\text { animais em } \\
\text { movimento } \\
\left(\mathrm{X}_{1}\right)\end{array}$ & $\begin{array}{l}\text { Nível de } \\
\text { imunização } \\
\text { estimado } \\
\left(\mathrm{X}_{2}\right)\end{array}$ & $\begin{array}{c}\text { Focos } \\
\text { confirmados } \\
(\mathrm{Y})\end{array}$ \\
\hline 1973 & Dez & 88.241 & 79,3 & 78 \\
\hline \multirow{5}{*}{1974} & Jan & 75.662 & 70,8 & 62 \\
\hline & Fev & 98.554 & 86,5 & 46 \\
\hline & Mar & 161.740 & 81,5 & 146 \\
\hline & $\mathrm{Abr}$ & 210.538 & 76,5 & 253 \\
\hline & Mai & 217.392 & 67,3 & 211 \\
\hline & Jun & 140.371 & 84,9 & 74 \\
\hline & Ju 1 & 68.977 & 81,7 & 39 \\
\hline & Ago & 47.659 & 78,4 & 32 \\
\hline \multirow{2}{*}{-} & Set & 37.052 & 70,7 & 23 \\
\hline & Out & 51.346 & 87,9 & 15 \\
\hline \multirow[t]{2}{*}{-} & Nov & 50.126 & 83,7 & 23 \\
\hline & Dez & 71.052 & 79,5 & 28 \\
\hline \multirow{6}{*}{1975} & Jan & 77.339 & 71,2 & 33 \\
\hline & Fev & 94.652 & 86,9 & 25 \\
\hline & Mar & 133.311 & 81,9 & 30 \\
\hline & $\mathrm{Abr}$ & 201.343 & 76,8 & 74 \\
\hline & Mai & 204.947 & 67,5 & 100 \\
\hline & Jun & 124.449 & 85,1 & 154 \\
\hline \multirow[t]{2}{*}{ - } & Nov & 78.476 & 83,6 & 69 \\
\hline & Dez & 86.467 & 79,4 & 79 \\
\hline 1976 & Jan & 92.888 & 71,1 & 79 \\
\hline \multirow[t]{9}{*}{1977} & $\mathrm{Abr}$ & 247.397 & 77,4 & 107 \\
\hline & Mai & 248.389 & 68,7 & 141 \\
\hline & Jun & 147.959 & 85,4 & 122 \\
\hline & Ju 1 & 78.139 & 80,8 & 46 \\
\hline & Ago & 77.130 & 77,8 & 29 \\
\hline & Set & 77.085 & 70,6 & 52 \\
\hline & Out & 92.134 & 88,9 & 46 \\
\hline & Nov & 100.661 & 84,1 & 9 \\
\hline & Dez & 111.552 & 79,3 & 24 \\
\hline
\end{tabular}


Tabela 10 - continuação.

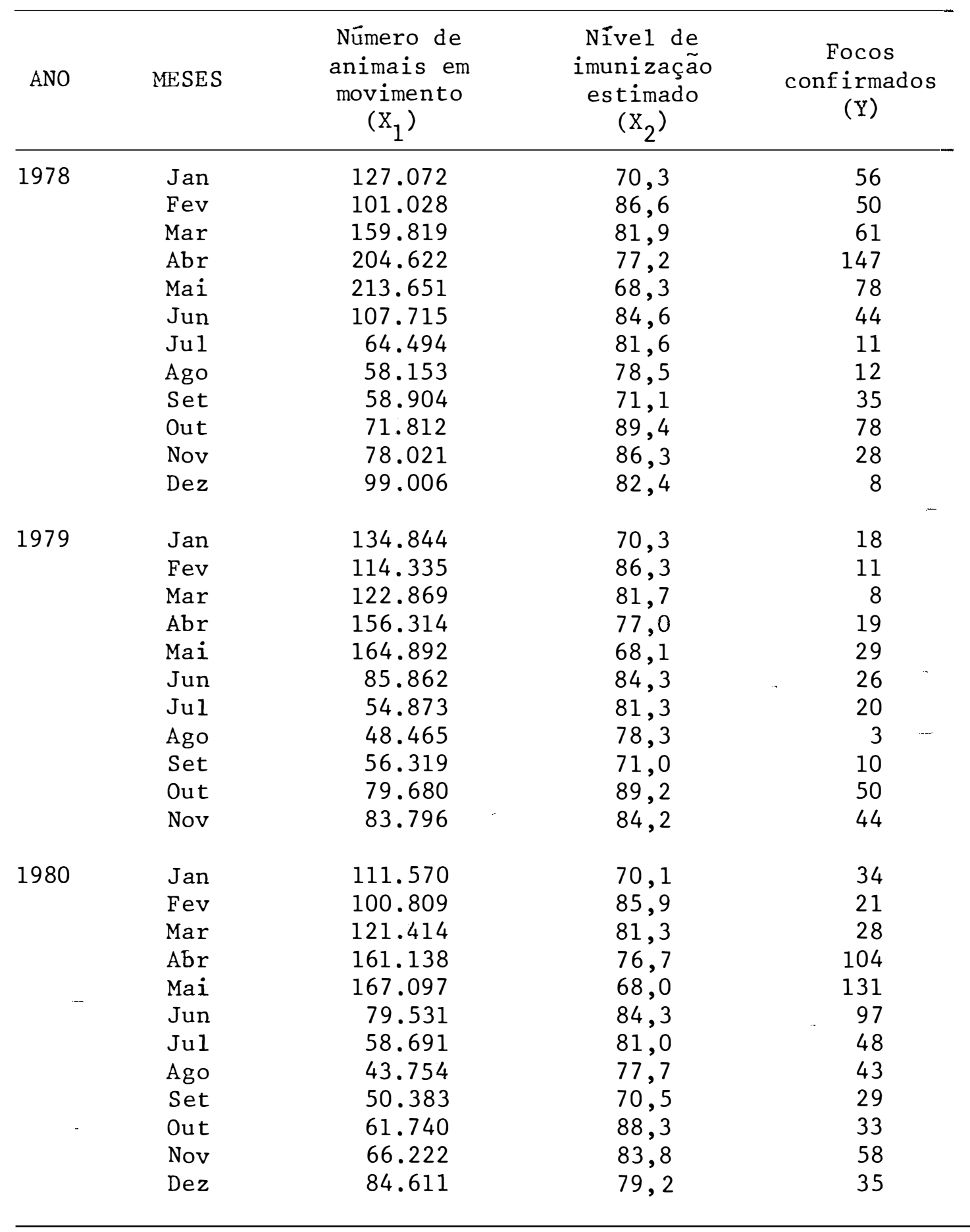


36.

$$
\begin{aligned}
& x_{1} \text { e } y: \\
& x_{1}, x_{2} \text { e } y: \\
& y=-9,22+0,00061 x_{1} \\
& y=-13,49+0,00061 x_{1}+0,051 x_{2} \\
& \begin{array}{l}
r_{x_{1}, y}=0,6599 * \\
r_{x_{1}, y}=0,4354
\end{array} \\
& \begin{array}{l}
r_{x_{2}, y}=-0,2186^{n s} \\
\quad r_{x_{2}, y}^{2}=0,0478
\end{array} \\
& \begin{array}{l}
r_{x_{1}, x_{2}}=-0,3403^{n s} \\
r_{x_{1}, x_{2}}^{2}=0,1158
\end{array} \\
& \begin{array}{l}
; \quad \mathrm{R}_{\mathrm{x}_{1} \mathrm{x}_{2}, \mathrm{y}}=0,6589 * \\
; \quad \mathrm{R}_{\mathrm{x}_{1} \mathrm{x}_{2}, \mathrm{y}}^{2}=0,4341
\end{array}
\end{aligned}
$$

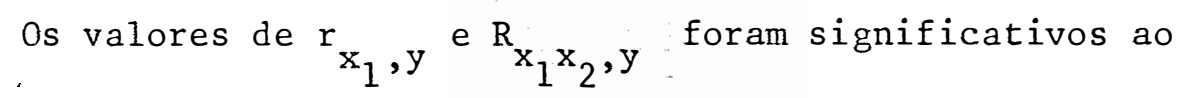

nível de $5 \%$ de probabilidade $(P<0,05)$. 
Tabela 11 - Movimentação de animais, nível de imunização estimado e número de focos confirmados, nos meses do período, considerados de alta frequência. Rio Grande do Sul, 1973-1980 .

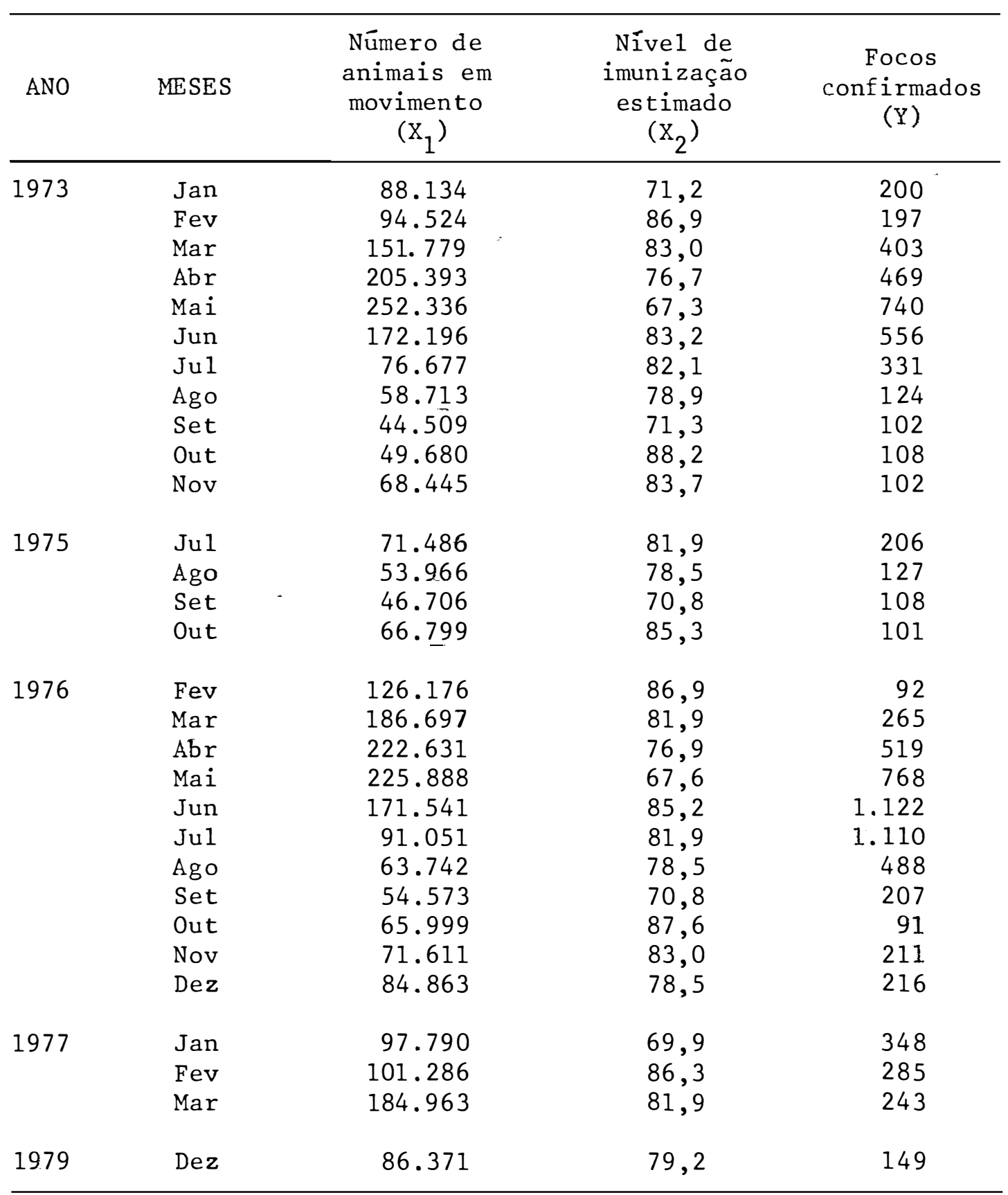




$$
\begin{aligned}
& x_{1} \text { e } y: \\
& y=39,44+0,00264 \\
& r_{x_{1}, y}=0,5783 * \\
& r_{x_{1}, y}^{2}=0,3345 \\
& r_{x_{1}, x_{2}}^{2}=-0,2015 \\
& r_{x_{1}, x_{2}}^{2}=0,0406
\end{aligned}
$$$$
x_{1}, x_{2} \text { e } y:
$$$$
y=173,86+0,0026 x_{1}-1,64 x_{2}
$$$$
\begin{aligned}
& \mathrm{r}_{\mathrm{x}_{2}, \mathrm{y}}=-0,1514^{\mathrm{ns}} \\
& \mathrm{r}_{\mathrm{2}_{2}, \mathrm{y}}=0,0229
\end{aligned}
$$$$
\begin{aligned}
& ; \quad \mathrm{R}_{\mathrm{x}_{1} \mathrm{x}_{2}, \mathrm{y}}=0,5794 * \\
& ; \quad \mathrm{R}_{\mathrm{x}_{1} \mathrm{x}_{2}, \mathrm{y}}^{2}=0,3357
\end{aligned}
$$

Os valores de $\mathrm{r}_{\mathrm{x}_{1}, \mathrm{y}}$ e $\mathrm{R}_{\mathrm{x}_{1} \mathrm{x}_{2}, \mathrm{y}}$ foram significativos ao nível de $5 \%$ de probabilidade $(P<0,05)$.

4.2 - Anālise da variāncia

\subsection{1 - Comparação dos anos e meses}

Com relação à incidência de focos dà doença no período em estudo, foi procedida a anâlise da variância, cujos resultados mostram diferenças significativas entre Anos e Meses. 


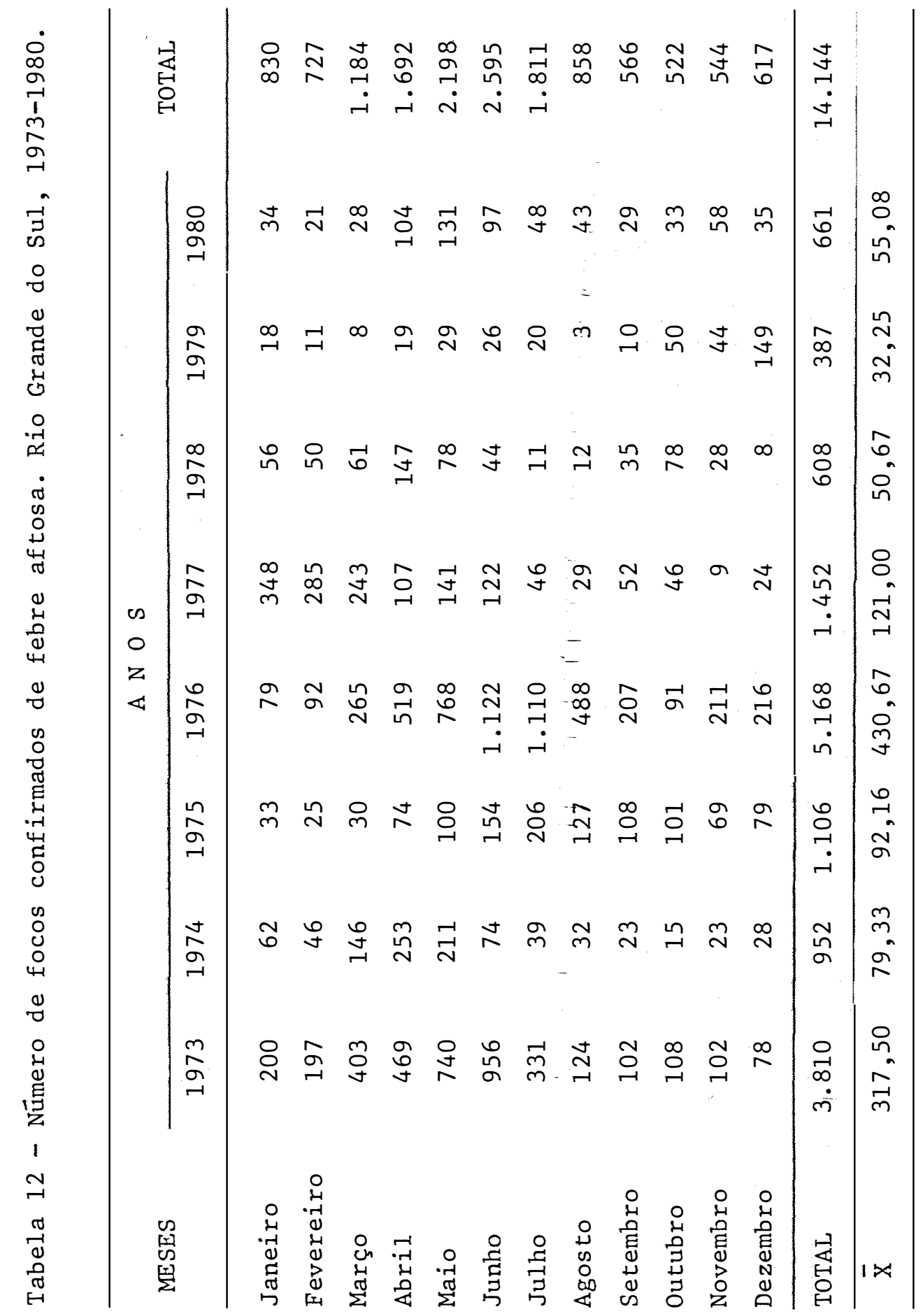


Na Tabela 13 apresentamos os resultados da anälise da variância.

Tabela 13 - Anālise da variância.

\begin{tabular}{lcccc}
\hline C. da Variação & G.L. & S.Q. & Q.M. & F- \\
\hline Tratamentos (Anos) & 7 & $1.789 .327,5$ & $255.618,21$ & $9,88 * *$ \\
Blocos (Meses & 11 & $707.708,3$ & $64.337,12$ & $2,49 *$ \\
Resíduo & 77 & $1.992 .938,5$ & $25.882,32$ & \\
\hline Total & 95 & $4.489 .974,3$ & & \\
\hline
\end{tabular}

O valor de F para Tratamentos (Anos) foi significati vo ao nível de $1 \%$ de probabilidade $(\mathrm{P}<0,01)$; quando ao vaìor de $\mathrm{F}$ para Blocos (Meses), este mostrou-se significativo ao nível-de $5 \%$ de probabilidade $(P<0,05)$.

\section{3 - Teste de Duncan}

a) Tratamentos (Anos)

Anos: 1979, 1978, 1980, 1974, 1975, 1977, 1973, 1976

Médias: 32,$25 ; 50,67 ; 55,08 ; 79,33 ; 92,16 ; 121,00 ; 317,50$;

$$
430,67
$$

$$
\begin{aligned}
\mathrm{D}_{8}=152,51 ; \mathrm{D}_{7} & =150,63 ; \mathrm{D}_{6}=148,77 ; \mathrm{D}_{5}=145,98 ; \\
\mathrm{D}_{4} & =142,72 ; \mathrm{D}_{3}=138,07 ; \mathrm{D}_{2}=131,10 .
\end{aligned}
$$



tivas, ao nível de $5 \%$ de probabilidade, quando comparadas as médias de focos dos anos:

- 1973 c/ 1974 a 1980 , exceto 1976;

- 1976 c/ 1974 a 1980.

Os demais contrastes não foram significativos.

b) Blocos (Meses)

Meses: Outubro, Novembro, Setembro, Dezembro, Fevereiro, Janeiro, Agosto

Médias: 65,$25 ; 68,00 ; 70,75 ; 77,13 ; 90,88 ; 103,75 ; 107,25$

Meses: Março, Abril, Julho, Maio, Junho

Médias: 148,$00 ; 211,50 ; 226,38 ; 274,75 ; 324,38$

$\mathrm{D}_{12}=193,39 ; \mathrm{D}_{11}=191,68 ; \mathrm{D}_{10}=189,41 ; \mathrm{D}_{9}=188,28 ;$

$\mathrm{D}_{8}=186,57 ; \mathrm{D}_{7}=184,29 ; \mathrm{D}_{6}=182,02 ; \mathrm{D}_{5}=178,60 ;$

$\mathrm{D}_{4}=174,62 ; \mathrm{D}_{3}=168,93 ; \mathrm{D}_{2}=160,42$.

Conclui-se que há diferenças estatisticamente significativas quando comparadas as médias dos focos dos meses:

- Junho c/ Janeiro, Fevereiro, Agosto, Setembro, Outubro, Novembro e Dezembro;

- Maio c/ Setembro, Outubro, Novembro e Dezembro. Os demais contrastes não foram significativos. 
Face aos resultados obtidos no presente estudo, tem-se a ressaltar que:

- Os anos de 1973, 1974, 1978 e 1980, do ponto de vista epidemiológico, podem ser considerados como endêmicos. A influência da movimentação de animais, neste caso, foi o fator mais importante no aumento de focos. Foi menor a contribuição do nível de imunização - quanto maior era o seu vảlor, menor a quantidade de focos da doen ça, embora os valores de $\mathrm{r}_{\mathrm{x}_{2}, \mathrm{y}}$ tenham sido baixos (Tabelas 1, 2, 6 e 8).

- Os anos de 1975, 1976, 1977 e 1979 apresentaram incidência maior de focos em períodos de menor movimentação de animais. Isto esclarece que esta característica não contribui, da mesma forma que no período considerado endêmico, para a difusão da doença. Desse mo do, estes anos seriam classificados como epidêmicos. A maior ocorrência de focos da doença nesse período poderia ser explicada pelo aparecimento de subtipos de vírus, atualmente plenamente identifica dos. Neste caso, o nível de imunização não apresentou nenhuma influência sobre a incidência de focos (Tabelas 3, 4, 5 e 7).

- A influência da movimentação de animais foi demonstrada atra vês da anālise de todo o período de estudo e com a utilização da mé dia aritmética dos meses. Convëm ressaltar a participação do nível de imunização na diminuição dos focos, embora este não tenha sido tão evidente (Tabela 9). 
- A movimentação de animais, fator decididamente responsāvel pe la incidência de focos, ficou evidenciada quando classificados os meses do período como endêmicos. O nível de imunização estimado demonstrou ser um componente que diminui a ocorrência de focos, porém, com uma ação limitada (Tabela 10).

- A verificação da análise do período considerado epidêmico de monstrou que a movimentação de animais não tem a mesma influência sobre a ocorrência de focos. Quanto ao nível de imunização estimado, não se apresentou tão importante na incidência da doença (Tabela 11).

- Uma queda em sua ocorrência (Tabela 12) pode ser observada quanto à incidência de focos ao longo de todo o período, com exceção do ano de 1976.

- Nos meses do 29 trimestre, de um modo geral, ocorreu maior número de focos em relação aos demais meses. Tal fato corrobora as anālises anteriores, pois são aqueles em que hā maior movimentação de gado em todo o Estado (Tabela 12).

- 0 nível de imunização estimado, adquirido atravês da vacinação ou contágio da doença, tem, pelos resultados obtidos, consonância com as citações feitas por diversos autores. Este, aumenta a re sistência dos animais frente à virulência da aftosa. 
44.

- Os resultados do presente trabalho estão de acordo com o CEN TRO PANAMERICANO DE FEBRE AFTOSA (1980), com ASTUDILLO et alii (1980) e MÁLAGA et alii (1976), ao verificar que a movimentação dos animais é o fator mais importante na ocorrência e disseminação da doen ça, entre os fatores que são considerados.

- Os coeficientes de correlação entre as variáveis $x_{1}$ e $x_{2}$, presentaram valores não significativos. 
45.

5. CONCLUSÕES

a) Considerando os meses de alta frequência, naqueles em que a ocorrência de focos da doença foi mais evidente, verificou-se que a influência da movimentação de animais no aparecimento de aftosa pode ser considerada menor que nos meses de baixa frequência.

b) Conforme os dados apresentados, verificou-se maior movimentação de animais no l'ọ semestre. Daí, pode-se depreender que isto possibilitaria aumentar a probabilidade de ocorrência de focos da doença.

c) Considerando que as vacinações ocorreram nos meses de janei ro, maio e setembro, verificou-se menor percentagem de susceptibili dade populacional nos meses de fevereiro, junho e outubro. Isto em razão do estímulo pós-vacinação e em consequência de um maior valor no nîvel de imunização estimado nestes meses. 
d) Nos meses endêmicos, ou seja, de baixa frequência de focos, há pouca presença de vírus. Vindo o período de maior movimentação de animais, aumenta bruscamente a quantidade de vírus em exposição e a taxa de contato, coincidindo com a fase em que hả maior número de animais susceptíveis, jâ que no final do ano é grande o número de nascimentos e, portanto, no 10 semestre do ano seguinte hä uma fração importante da população com baixa imunidade.

e) Considerou-se, de acordo com as fontes pesquisadas, sobre a imunidade adquirida pelos animais após vacinação, que a metodologia adotada, para determinação das estimativas do nível de imunização da populaçãó bovina, pode ser utilizada em outras experiềncias. Isto porque, com o tempo transcorrido apōs a vacinação, há uma diminuição do nível de anticorpos circulantes, embora ocorra-um aumento do nível de imunização com a idade.

f) Quanto à aquisição de um nível de imunização satisfatōrio, através das vacinações, faz-se necessärio um controle oficial rigoroso da qualidade das vacinas e uma garantia de boa aplicação.

g) Quanto à incidência de focos da doença, verificou-se que a diminuição ocorrida durante o período observado foi significativa. Provavelmente, fruto de medidas de caráter sanitärio adotadas no controle da doença. 
h) Com relação à anālise comparativa dos meses, observou-se que ocorreu uma diferença significativa. O período de março a julho mos trou-se como sendo de maior incidência, isto como consequência, naquele período, da maior movimentação de animais.

i) Quanto à movimentação de animais, no segundo semestre, esta se destina, em sua maioria, à mudança de animais de certas regiões para outras, por razões de manejo, o que poderia justificar a baixa frequência de focos nesse período. 


\section{LITERATURA CITADA}

ADEMOLLO, A., 1959. Inspection, dans les aéroports des animaux et produits d'animaux. Bulletin Off. Int. Epiz, Paris, 52: 97-117.

ANSELMO, F.P.; E.C. MOREIRA; S. OLINDA; J.S. SANTANA e M.L.R. ARAUJO, 1976. Incidência da febre aftosa em bovinos na região do Triangu1o, Minas Gerais. Arq. Esc. Vet. U.F.M.G., Belo Horizonte, 28(2): 131-140.

ASTUDillo, V.M.; R. DEPPERMANN e M.T. GAUTO, 1973. Canales de comunicaciōn y velocidad de transmisiōn en sistemas de información pạ ra fiebre aftosa. Seminārio regional sōbre sistemas de vigilância epidemiológica de enfermedades transmisibles y zoonosis. Doc. no 3, Rio de Janeiro, 2-8 de deciembre, 1973.

ASTUDILLO, V.M.; A.M. SILVA; J.F.P. DORA; R. DEPPERMANN e M. COSTA, 1980. Tempo-presença como indicador para la caracterización epide miológica de la fiebre aftosa. Informe Epidemiológico del Centro.

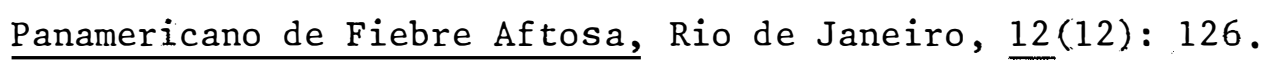

ASTUDILLO, V.M., 1982. Vigilância epidemiológica no Estado do Rio Grande do Sul. Boletim del Centro Panamericano de Fiebre Aftosa, Rio de Janeiro. (No prelo). 
AUGE DE MELLO, P.; V. ASTUDILlO; I. GOMES e J.T. CAMPOS GARCIA, 1977. Respuesta inmunitaria de bovinos adultos vacinados contra la fiebre aftosa con vacina oleosa. Boletin del Centro Panamericano de Fiebre Aftosa, Rio de Janeiro, 26: 23-25.

BACHRACH, H.L., 1972. Fiebre aftosa. Boletin del Centro Panamericano de Fiebre Aftosa, Rio de Janeiro, 7: 1-40.

BEKKUM, J.G., 1970. Utilizacion y experiencias con la vacina tipo Frenkel. Revista Veterināria Venezoelana, Caracas, 29(168): 3-12.

BEKKUM, J.G.; R.C. FISH e C.N. DALE, 1963. Inmunogenic studies in dutch cattle vaccinated with foot-and-mouth disease vaccines under field conditions. I. Neutralizing antibody responses and immunity to $0, A$ and $C$ types. American Journal of Veterinary Research, Schaum burg, USA, $24(98): 77-82$, jan.

BEKKUM, J.G.; R.C. FISH e I. NATHANS, 1969. Immunologic responses in dutch cattle vaccinated with foot-and-mouth disease vaccines under field conditions: neutralizing antibody responses and immunity to 0 , A and C types. American Journal of Veterinary Research, Schaum burg, USA, $30(12): 2125-2129$.

BEKKUM, J.G., 1977. Factores que afectan la calidad de las vacinas de fiebre aftosa. Boletin de Informacion Científica y Técnica, San tiago, 18: 32-43.

BRADFORD HILL, A., 1956. Principles of medical statistics, 6. ed., New York, Oxford University Press, 314 p. 
CALLIS, J.J., 1970. Nuevas vacinas y perspectivas sobre inmunizáción contra la fiebre aftosa. Revista Veterināria Venezoelana, Caracas, $29(168): 68-77$.

CENTRO PANAMERICANO DE FEBRE AFTOSA, 1978. Resumen de las investigaciones actuales realizadas en el Centro Panamericano de Fiebre Aftosa sobre vacinas de adyuante oleoso, Rio de Janeiro, 33 p.

CENTRO PANAMERICANO DE FEBRE AFTOSA, 1979. Projeto de estudo de perdas de produção e produtividade em gado bovino com febre aftosa; plano de desenvolvimento do estudo, Rio de Janeiro, out., 59 p.

CENTRO PANAMERICANO DE FEBRE AFTOSA, 1980. Ecosistemas de febre afto sa no Estado do Rio Grande do Sul, Centro Panamericano de Febre Af tosa, Rio de Janeiro, $52 \mathrm{p}$.

CENTRO PANAMERICANO DE FEBRE AFTOSA, 1981. Evaluacion de proyectos de vacunacion de bovinos con adyuante oleoso del Centro Panamericano de Fiebre Aftosa, Rio de Janeiro, jun., 148 p.

CENTRO PANAMERICANO DE FEBRE AFTOSA, 1982. Resoluciones y recomendaciones de la comision sudamericana para la lucha contra la fiebre aftosa, 1973-1981, Rio. de Janeiro, 86 p.

CHAPPUIS, G. e Y. MOREAU, 1972. Anticorps et immunité anti-aphteuse chez les bovins. Bul1. Off. Int. Epizooties, Paris, 77(5-6): 965-983 . 
FEDIDA, M.; G. DANNACHER; M. COUDERT; M. PEILlON e F. LUCAM, 1972. Evolution et dureé de l'immunité anti-aphteuse post-vaccinale chez les bovins pluri-vaccinés. Bull. Off. Int-Epizooties, Paris, 77 $(5 / 6)$ : 1005-1027.

FERNANDES, N.V., 1972. Ultimos avances en vacunas contra la fiebre af tosa. Boletin del Centro Panamericano de Fiebre Aftosa, Rio de Ja neiro, 8: $1-14$.

FERNĀNDEZ, A.A. e M.S. SÖNDAHL, 1975. Imunologia. Rio de Janeiro, Centro Panamericano de Febre Aftosa, 32 p. (Manuais Didáticos, 3).

GOMES, I.; P. SUTMOLLER e R.C. OLASCOAGA, 1980. Respuesta en bovinos a la exposicion del vírus de la fiebre aftosa un año despues de inmunizados con vacuna con adyuante oleoso. Boletin del Centro Panamericano de Fiebre Aftosa, Rio de Janeiro, 37-38: 25-29.

GUERREIRO, M.G., 1955. A epizootiologia da febre aftosa no Rio Grande do Sul, nos anos de 1950-53. Arquivos do Instituto de Pesquisas Veterinärias Desiderio Finamor, 1: 75-82.

HONIGMAN, M.N.; I. GOMES; I. ABREU MARTINS e R.A. LOMBARDO, 1971. Per sistencia en terneros de la inmunidad post vacunal contra el vírus aftoso. Boletin del Centro Panamericano de Fiebre Aftosa, Rio de Janeiro, 2: 12-20.

HUGH-JONES, M.E., 1972. Epidemiological studies on the 1967/1968 foot-and-mcuth disease epidemic: attack rates and cattle density. Rev. Vet. Sci., England, 13(5): 411-417.

HYSLOP, N.G., 1972. La epizootiologia y epidemiologia de la fiebre af tosa. Boletin del Centro Panamericano de Fiebre Aftosa, Rio de Janeiro, 5: 1-48. 
KHUKHOROV, V.M.; T.Z. BAIBIKOV e U.V. FEOKTISKOV, 1978. Un estudio sobre la inmunidad colostral en terneros nacidos de vacas convalecientes de fiebre aftosa. Veterinariya. (Moscow), 9: 40-41.

LOBO, C.A., 1975. Inmunizacion en fiebre aftosa. IN: INSTITUTO CO LOMBIANO AGROPECUARIO. La fiebre aftosa y otras enfermedades vesiculares en Colombia. Bogotá, 57-65.

LUCAM, F.; M. FEDIDA; G. DANNACHER e J. PERRAUD, 1969. Evolution et dureé de l'immunité ant-aphteuse chez le boeuf primovacciné. Bulletin Off. Int. Epiz., Paris, 71(3-4): 463-484.

MACKOWIAK, C.; R. LANG; J. FONTAINE; R. CAMAND e H.G. PETERMANN, 1962. Étude de la dureé de l'immunité conférée par le vaccin ant-aphteux. Bul1. Off. Int. Epiz., Paris, 57(5/6): 781-792.

MÁLAGA, H.; M. WANDERLEY; H. DE CANAL; V. SARAIVA; R. AZEREDO; A. PA LETEIRO; F. DORA; J.C. COELHO; W. SANTOS e C. REMIGIO, 1976 . Observaciones sobre el riesgo de ocurrencia de fiebre aftosa. Boletin del Centro Panamericano de Fiebre Aftosa, Rio de Janeiro, 23$-24: 51-56$.

MOURAVIEV, V.K.; V.P. ONOUFRIEV e V.I. CHORCHNEV, 1972. Etude de l'immunité post-vaccinale à l'égard de la Fièvre Aphteuse chez les bovins. Bull. Off. Int. Epiz., Paris, 77(5/6): 901-911.

MUNTIU, N., 1969. L'immunité post-vaccinale dans la Fièvre Aphteuse et les principaux facteurs dont elle dépend. Bull. Off. Int. Epiz., Paris, 72: 1133-1155.

MUNTIU, N.; V. DOHOTORAU; A. BERCAN; G. MIRCESCU; A. TOMESCU e C. STIR BU. 1969. Effect of age of cattle on the postvaccinale FMD immunity. Eur. Comm. Cont. FMD MTg. Res. Gip. Std. Coom., Brescia (Italy). 
MUNTIU, N.; A. DUMISTRESCU; V. DOHOTARU; T. NEGRUTIU; A. BERCAN; G. MIRCESCU; C. STIRBU e A. TOMESCU, 1972. Durée de l'immunité postvaccinale contre la Fièvre Aphteuse par rapport a l'âge des animaux, à la dose de vaccin et a la répetition de la vaccination. Bull. Off. Int. Epiz., $77(5-6): 771-787$.

OBIAGA, J.A.; F.J. ROSENBERG; V. ASTUDILLO e R.M. GOIC, 1979. Las características de la preducción pecuāria como determinantes de los ecosistemas de fiebre aftosa. Boletin del Centro Panamericano. de Fiebre Aftosa, Rio de Janeiro, 33-34: 33-42.

OLIVEIRA, S.B., 1973. Febre Aftosa. São Paulo, Secretaria da Agricultura. Coordenadoria de Assistência Técnica Integral, 36 p.

PARDI, M.C. e R.B. CALDAS, 1968. Grandes deslocamentos de gado bovino de corte no Brasil. IN: CONGRESSO BRASILEIRO DE VETERINĀRIA, 11 , CONGRESSO FLUMINENSE DE MEDICINA VETERINĀRIA, 1. Niterói, 1968. Anais do Congresso Brasileiro de Veterināria, 11, Congresso Fluminense de Medicina Veterināria, 1, Niteröi, Sociedade Brasileira de Medicina Veterināria, v. 2, p. 126.

PIMENTEL GOMES, F., 1978. Curso de Estatística Experimental, 8. edição, Livraria Nobel S.A., São Paulo, 430 p.

ROSENBERG, F.J. e M.R. GOIC, 1972. Programas de control y prevencion de la fiebre aftosa en las Américas. Boletin del Centro Panamericano de Fiebre Aftosa, Rio de Janeiro, 8: 15-16.

ROSENBERG, F.J. e M.R. GOIC, 1973. Programas de control y prevencion de la fiebre aftosa. Boletin del Centro Panamericano de Fiebre Aftosa, Rio de Janeiro, 12: 1-22. 
SCHNEIDER, B.; G. JAEGER e H.J. BENGELSDORF, 1964. Durée de 1'immunité et taux des anticorps déterminés chez les bovins par l'utilisation de vaccins anti-aphteux adsorbés préparés avec du virus obtenu en culture tissulaire. Bull. Off. Int. Epiz., Paris, 61 (9-10): 1013-1023.

SNEDECOR, G., 1956. Statistical Methods, 5. ed., The Iowa State College Press, Ames, Iowa, $534 \mathrm{p}$.

SUTMÖLLER, P.; K. FREITAS COSTA e I. GOMES, 1980. Prueba de seroneutralizacion por microtecnica para fiebre aftosa: calculo de la expectativa porcentual de proteccion. Boletin del Centro Panamericano de Fiebre Aftosa, Rio de Janeiro, 39-40: 31-36. 
55.

7. APENDICE: Cartogramas do Estado do Rio Grande do Sul mostrando a movimentação de animais ocorrida naquele Estado, segun do a quantidade de animais, o sentido da movimentação, bem como a sua finalidade, ou seja, abate ou cria. 


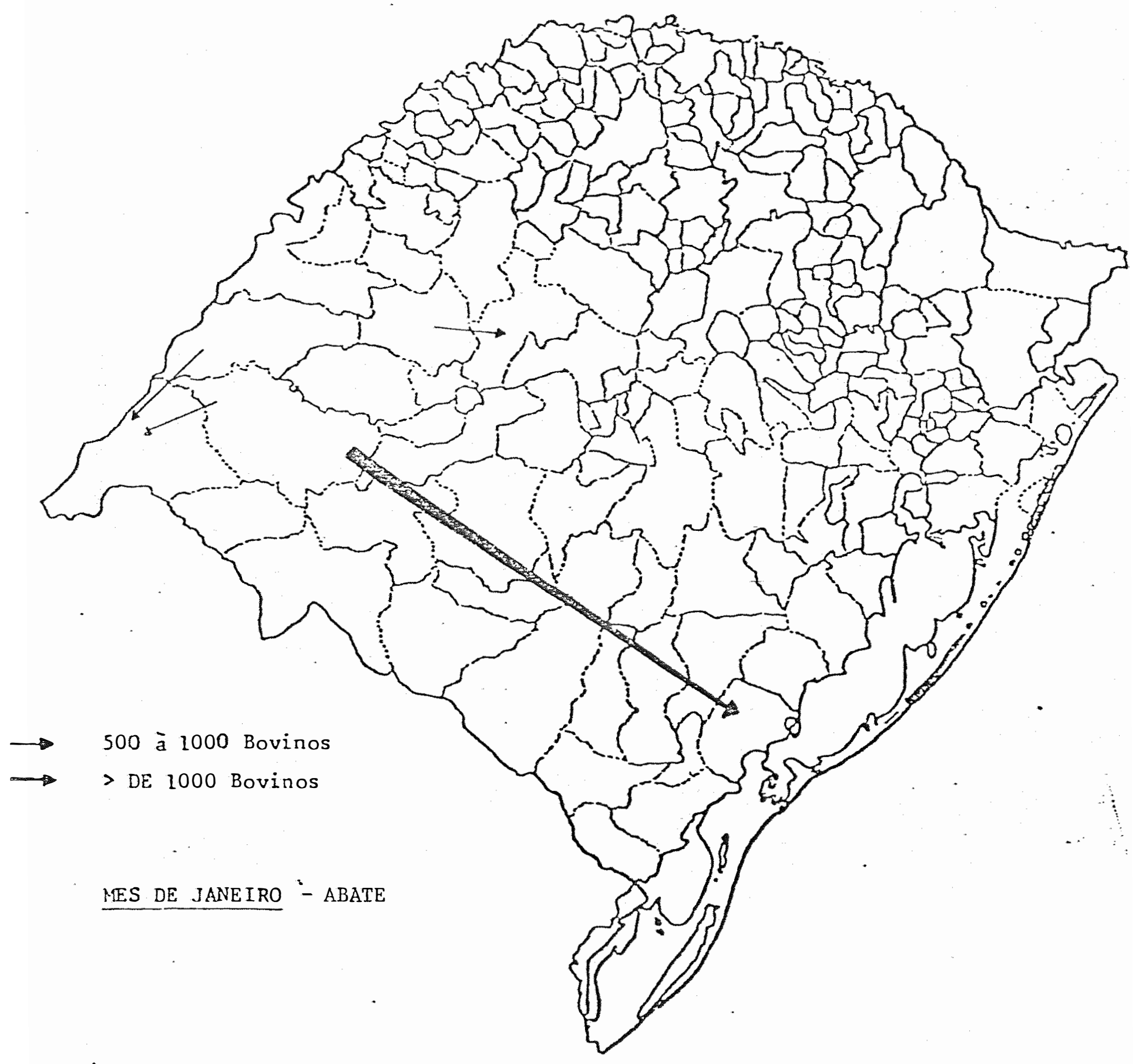




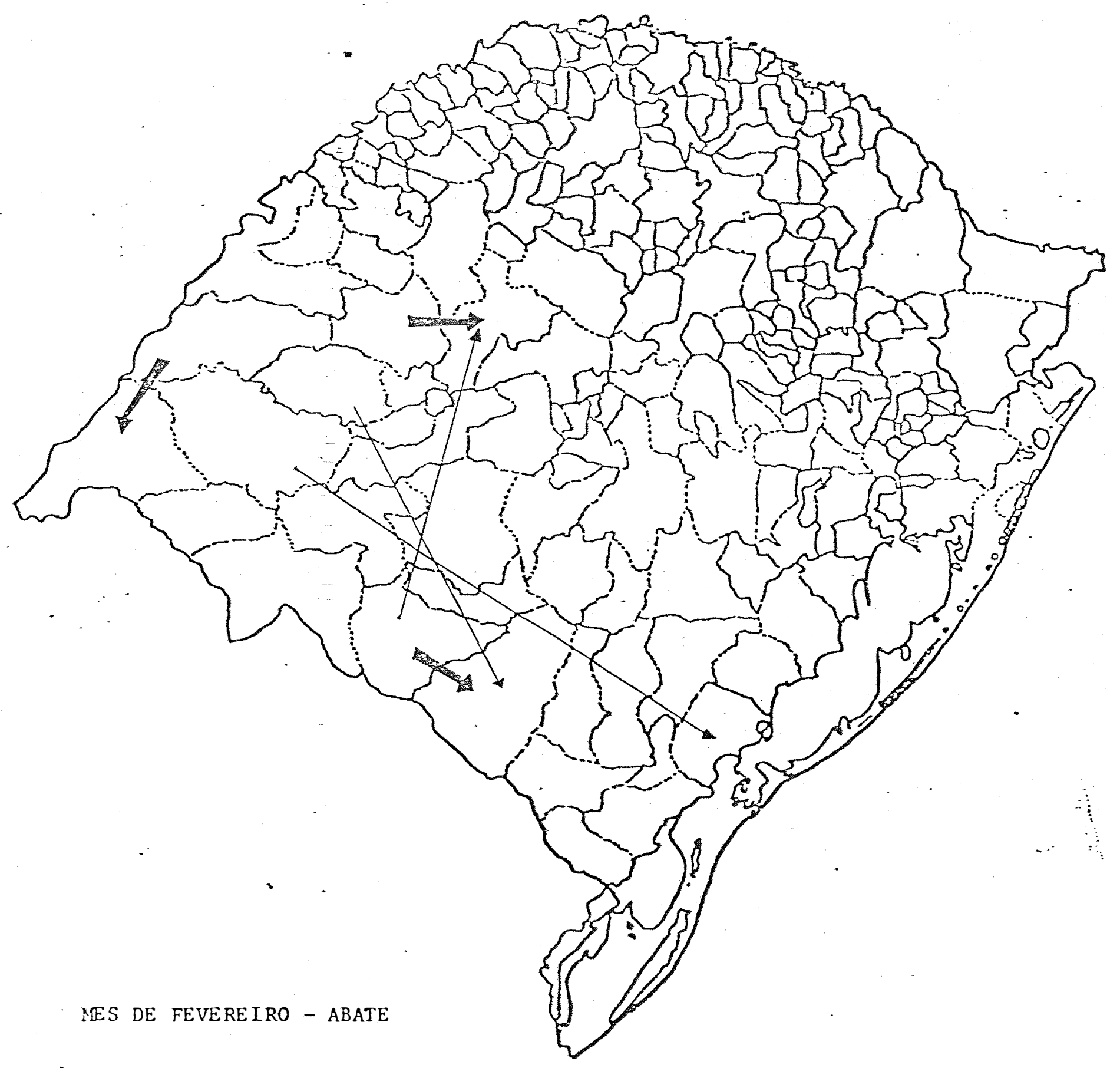




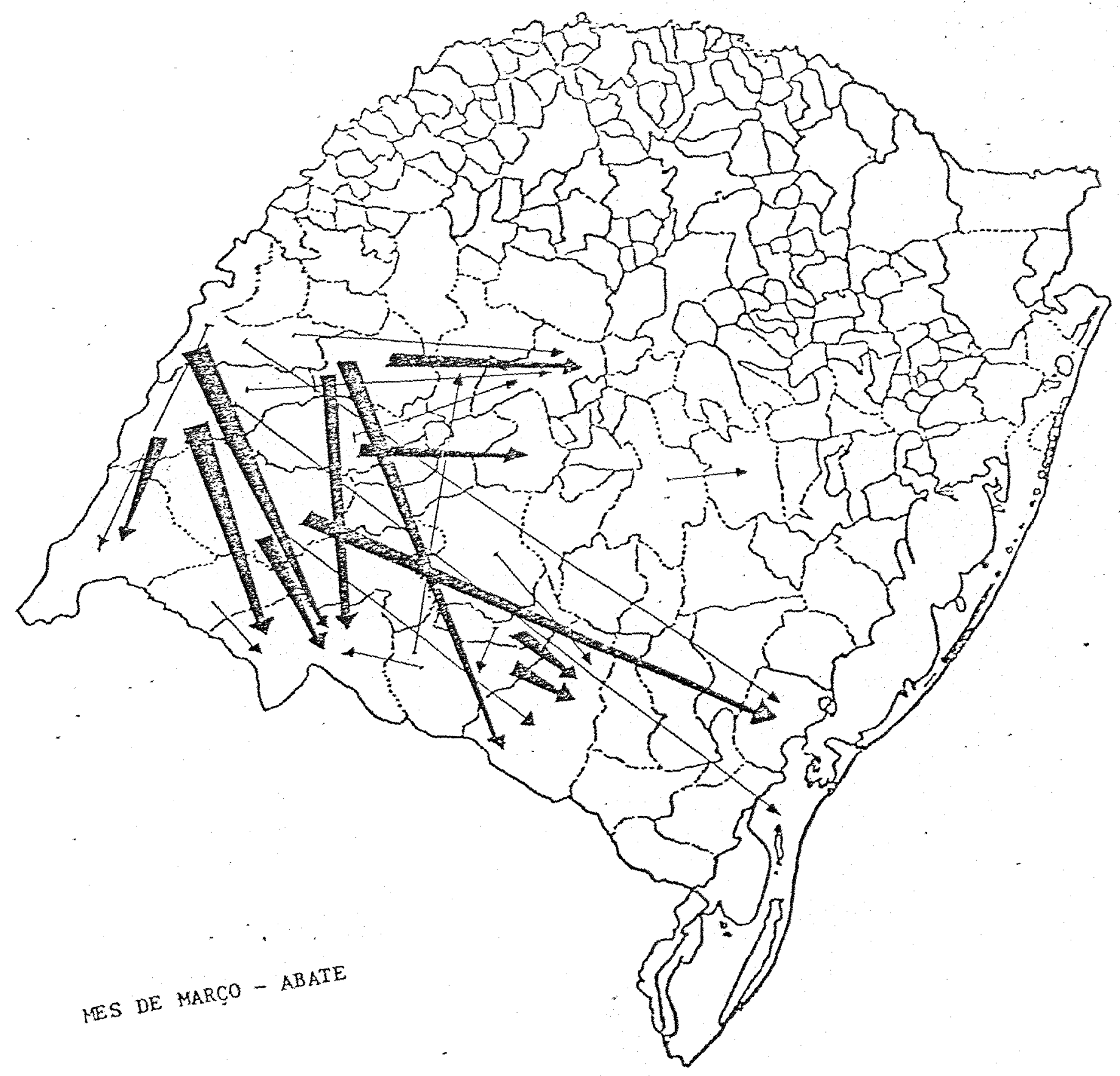




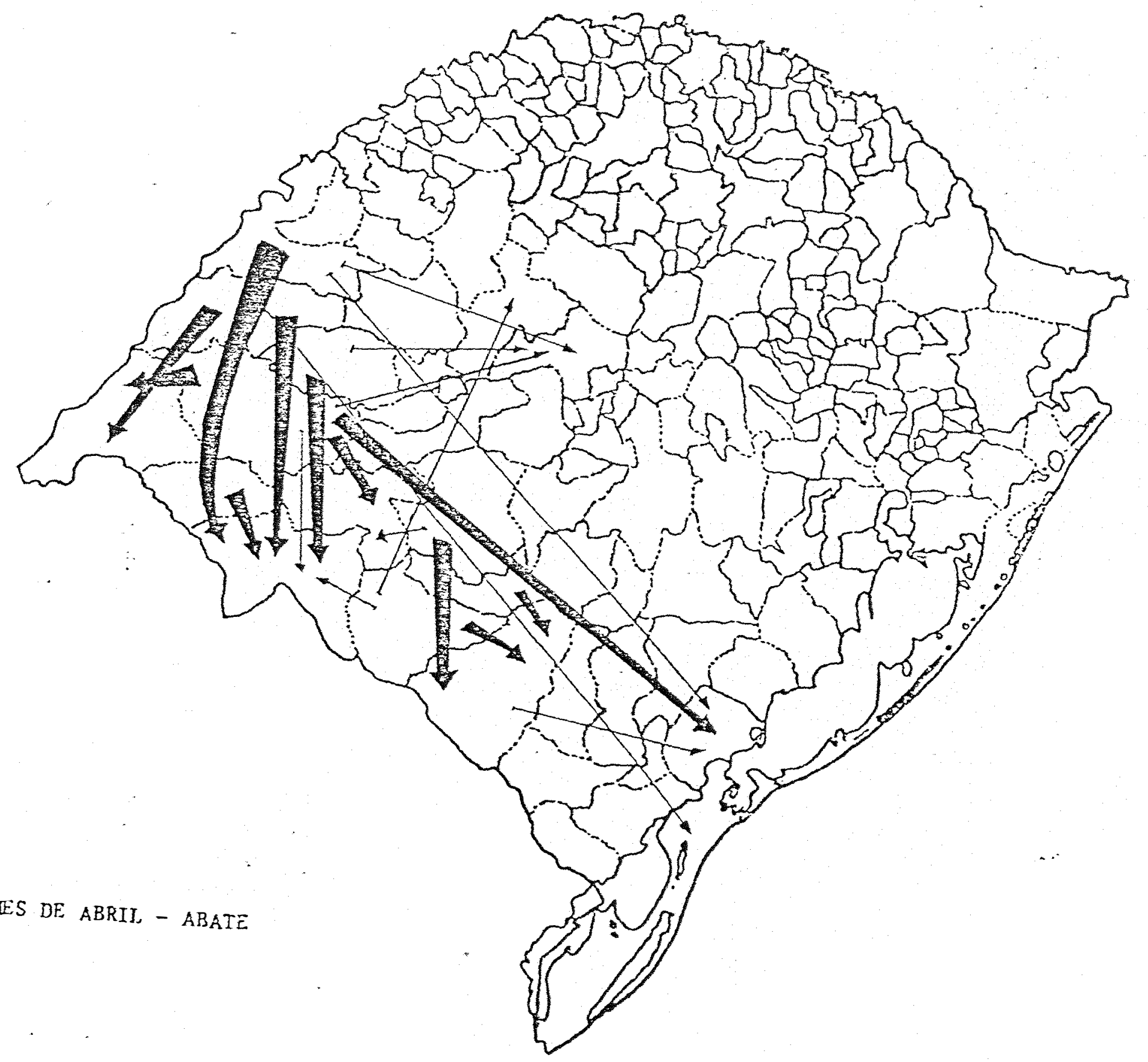




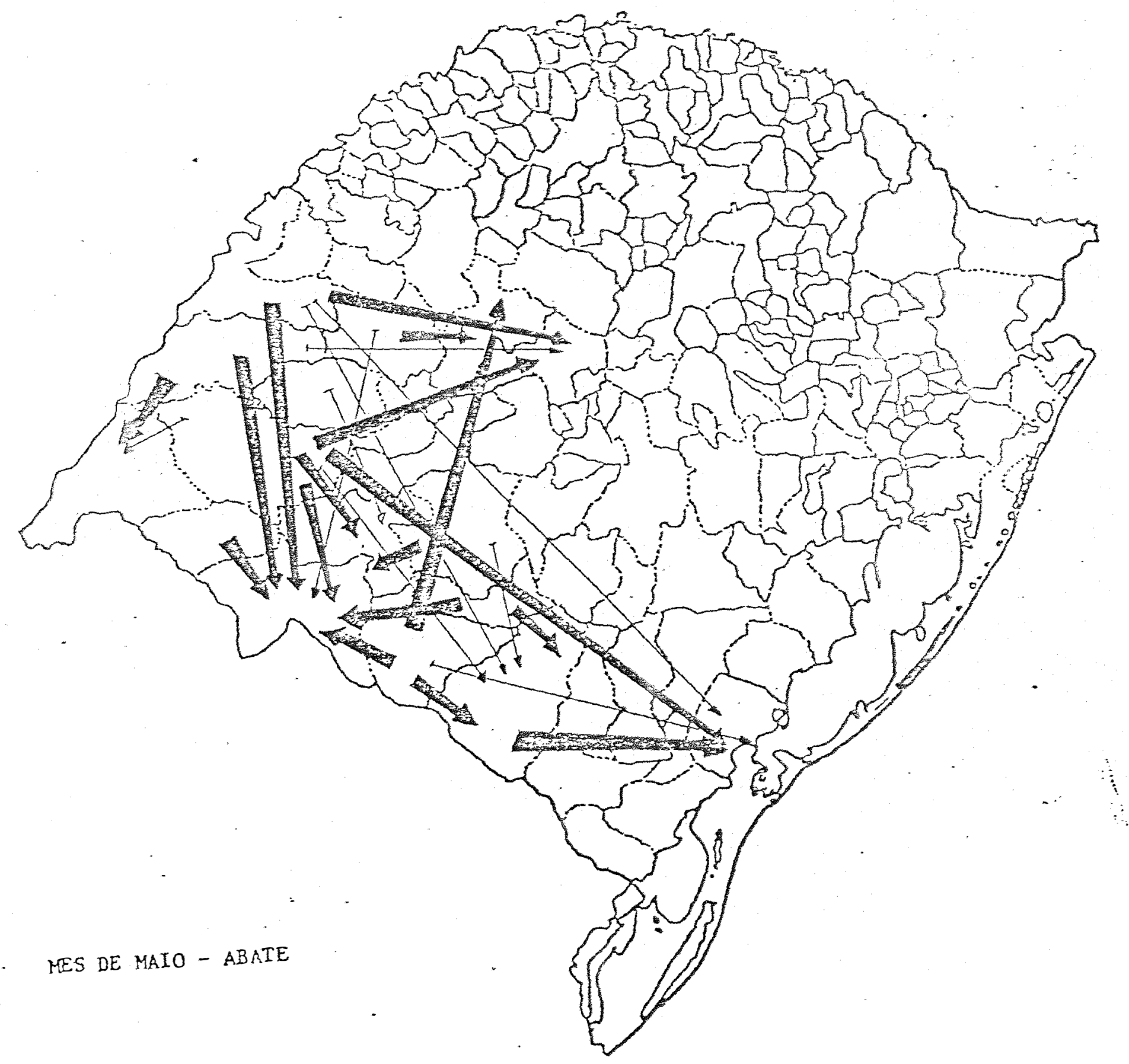




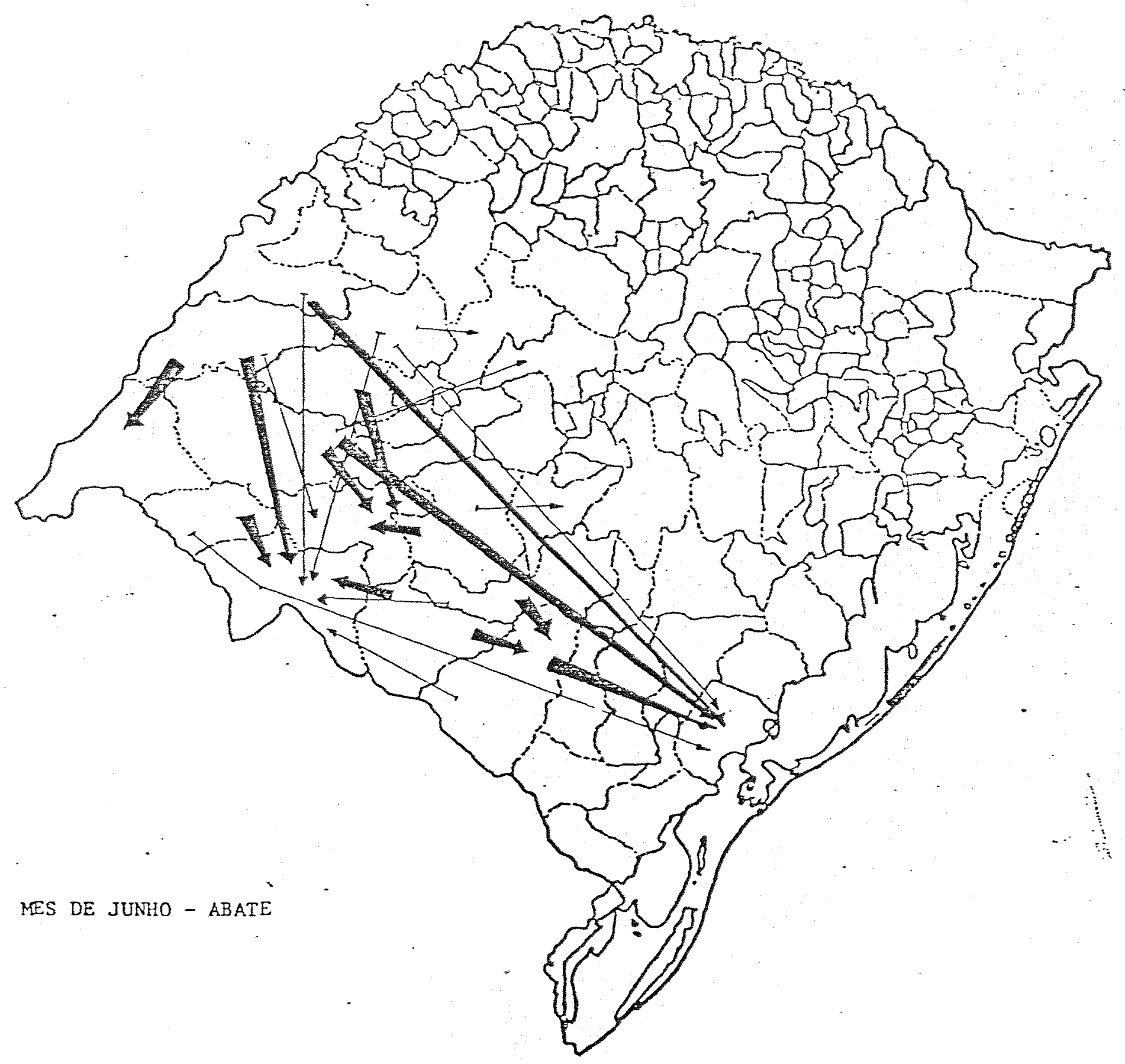




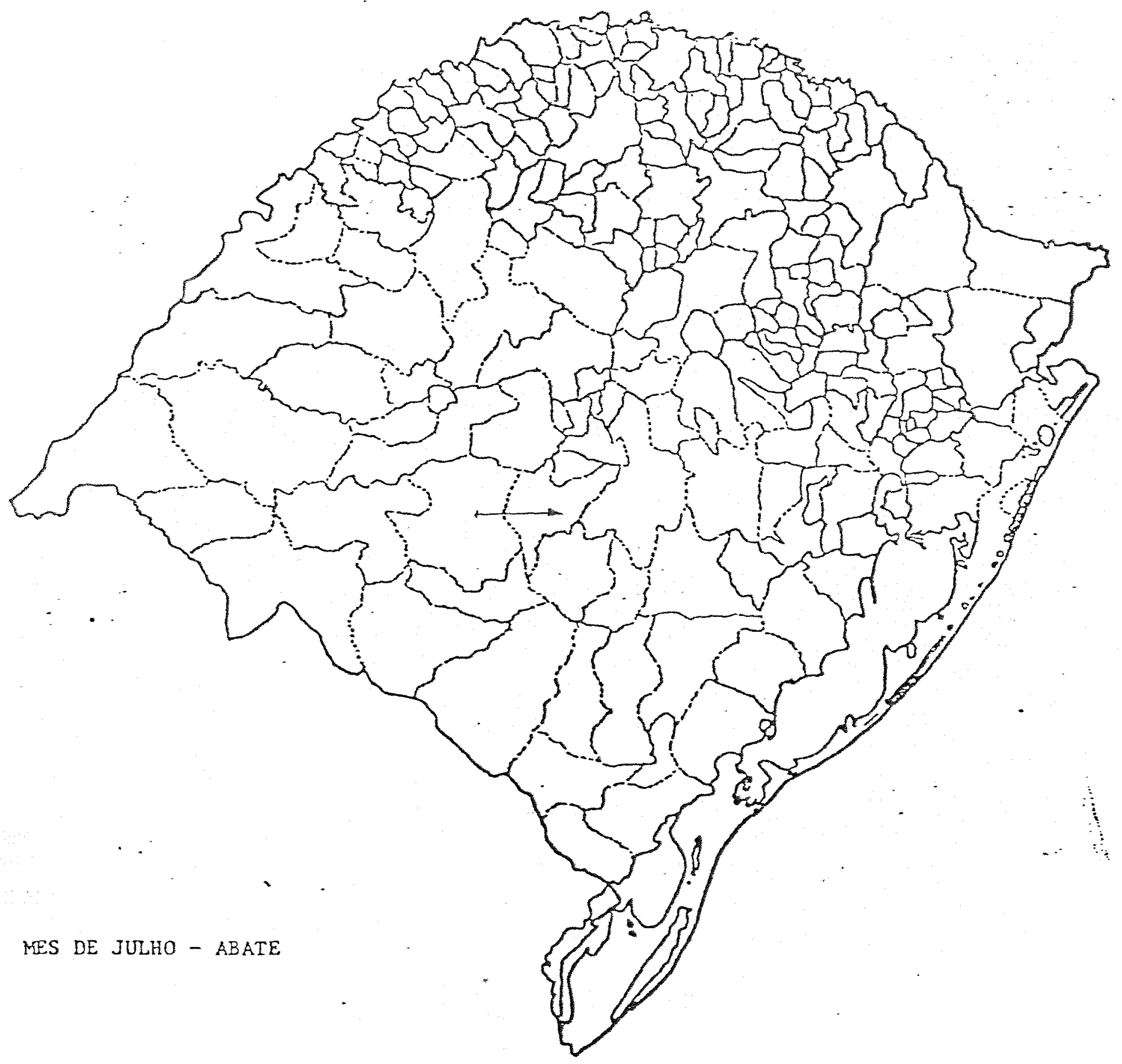




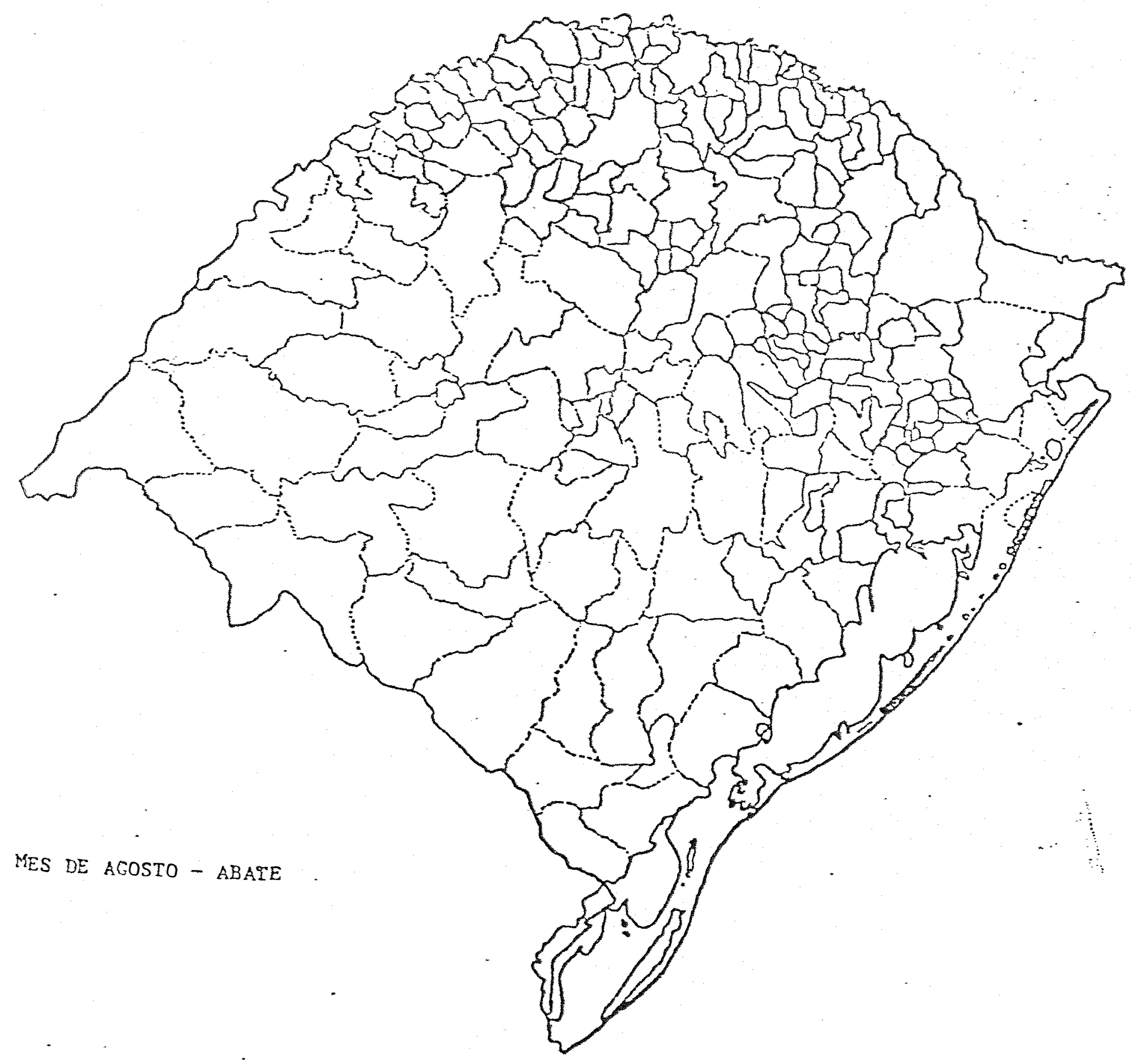




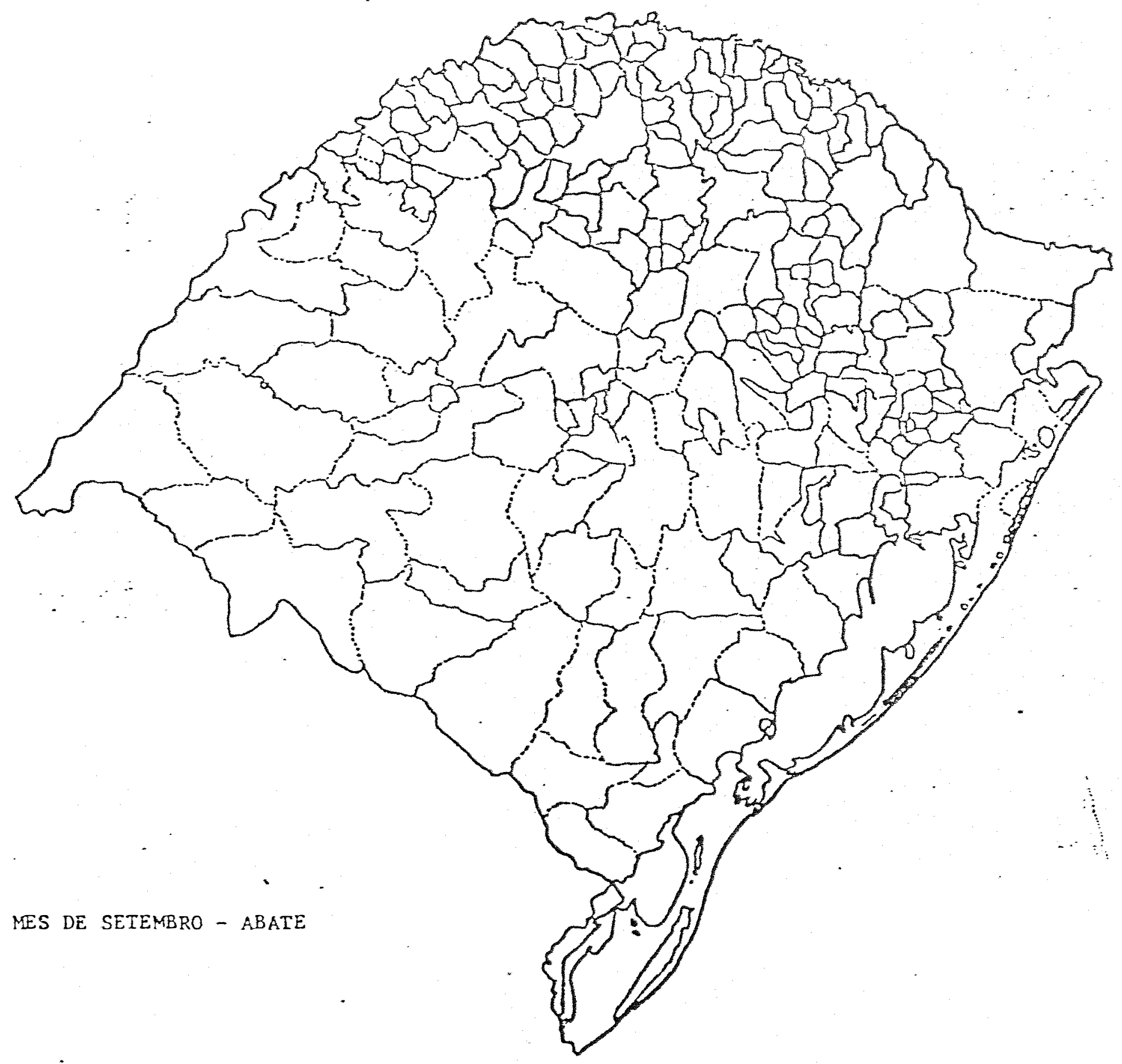




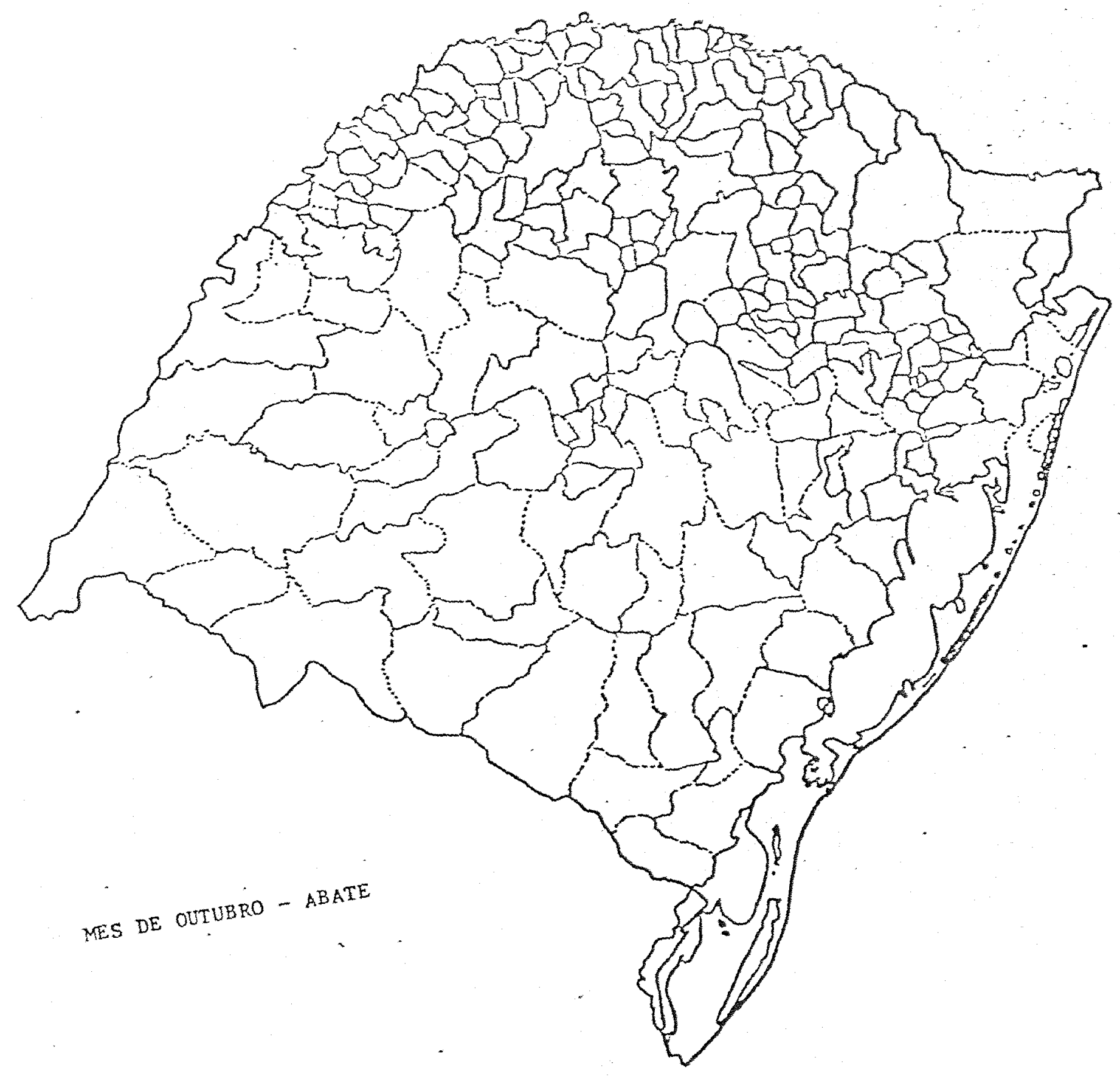


66.

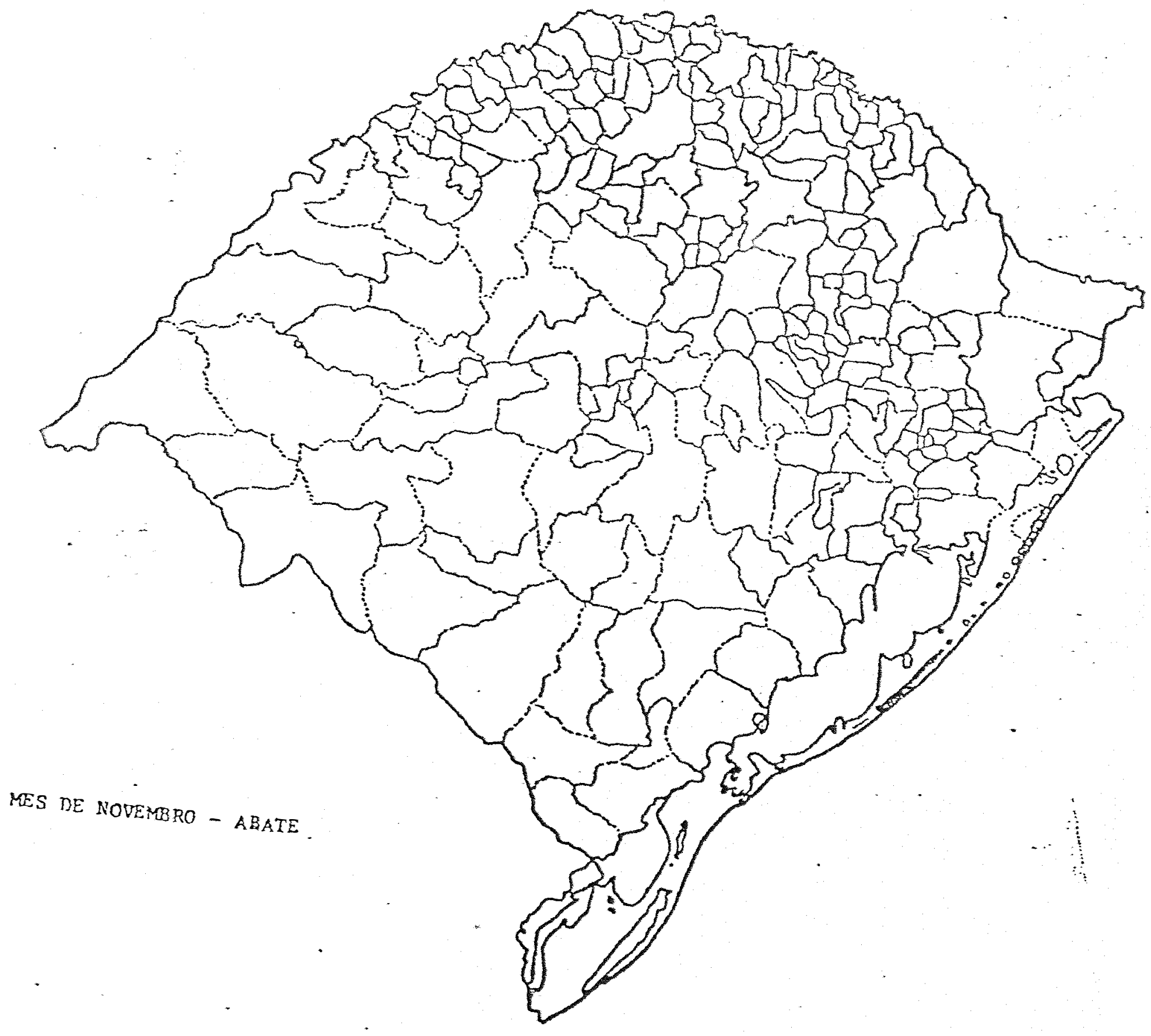




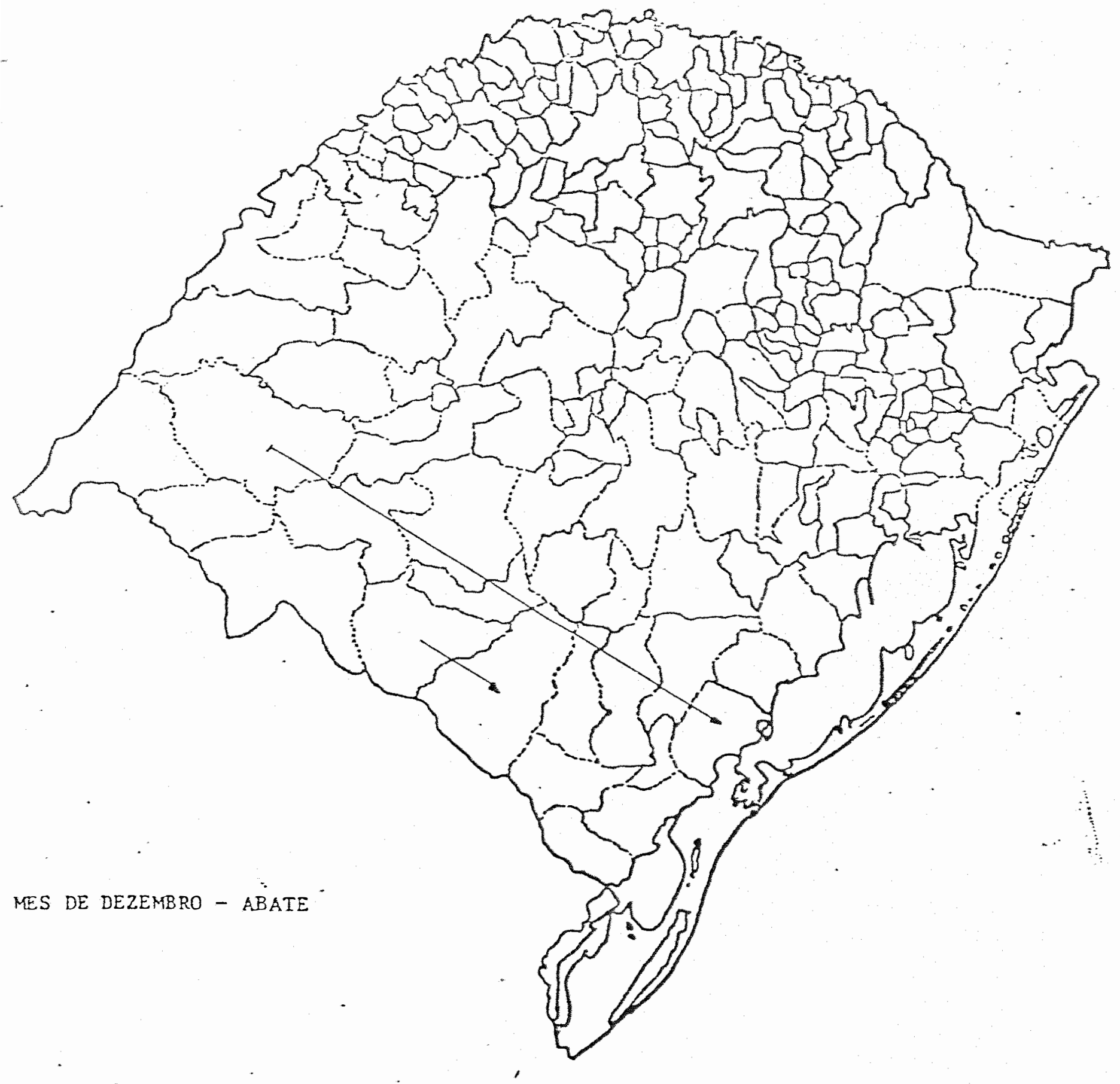




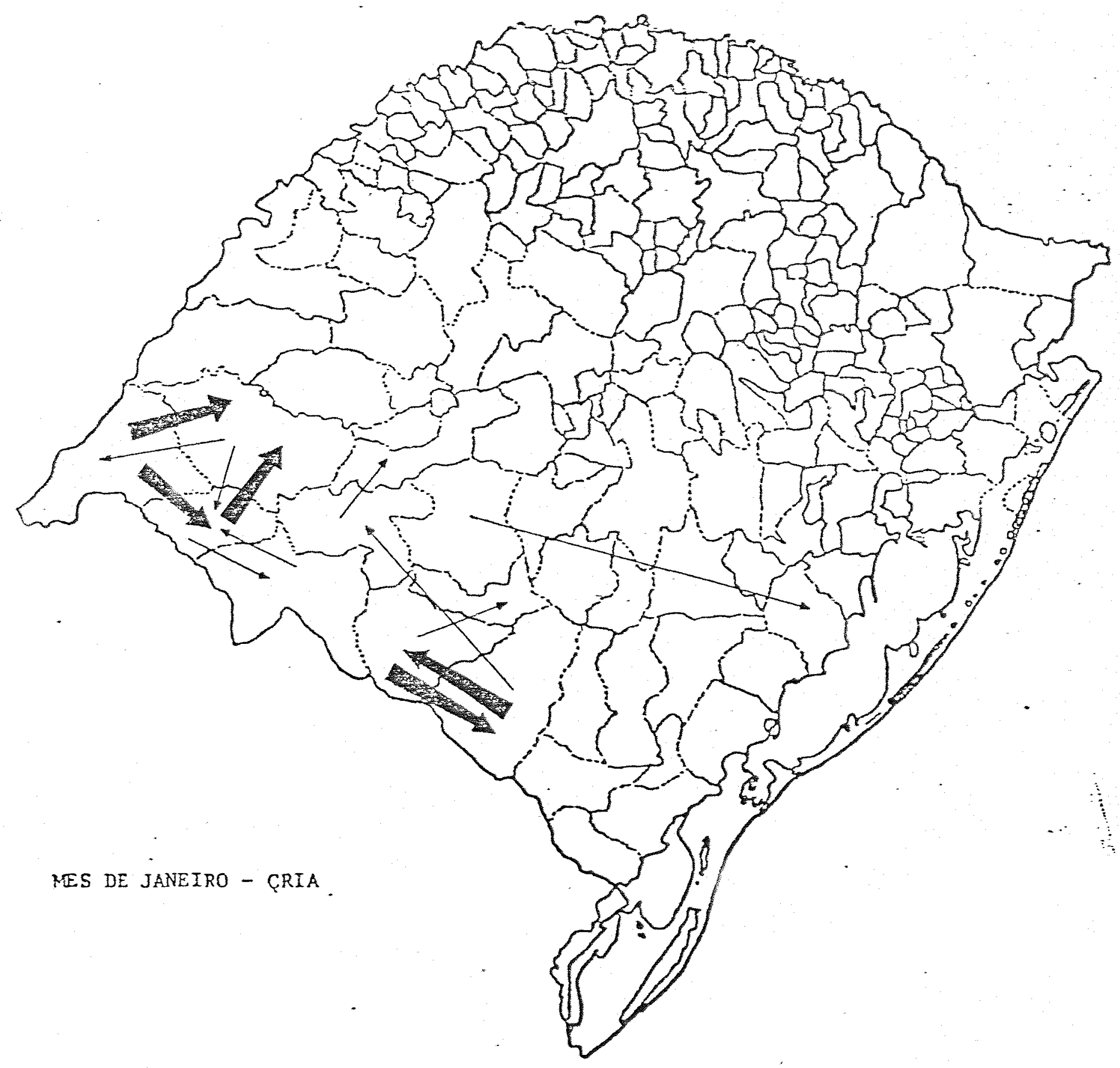




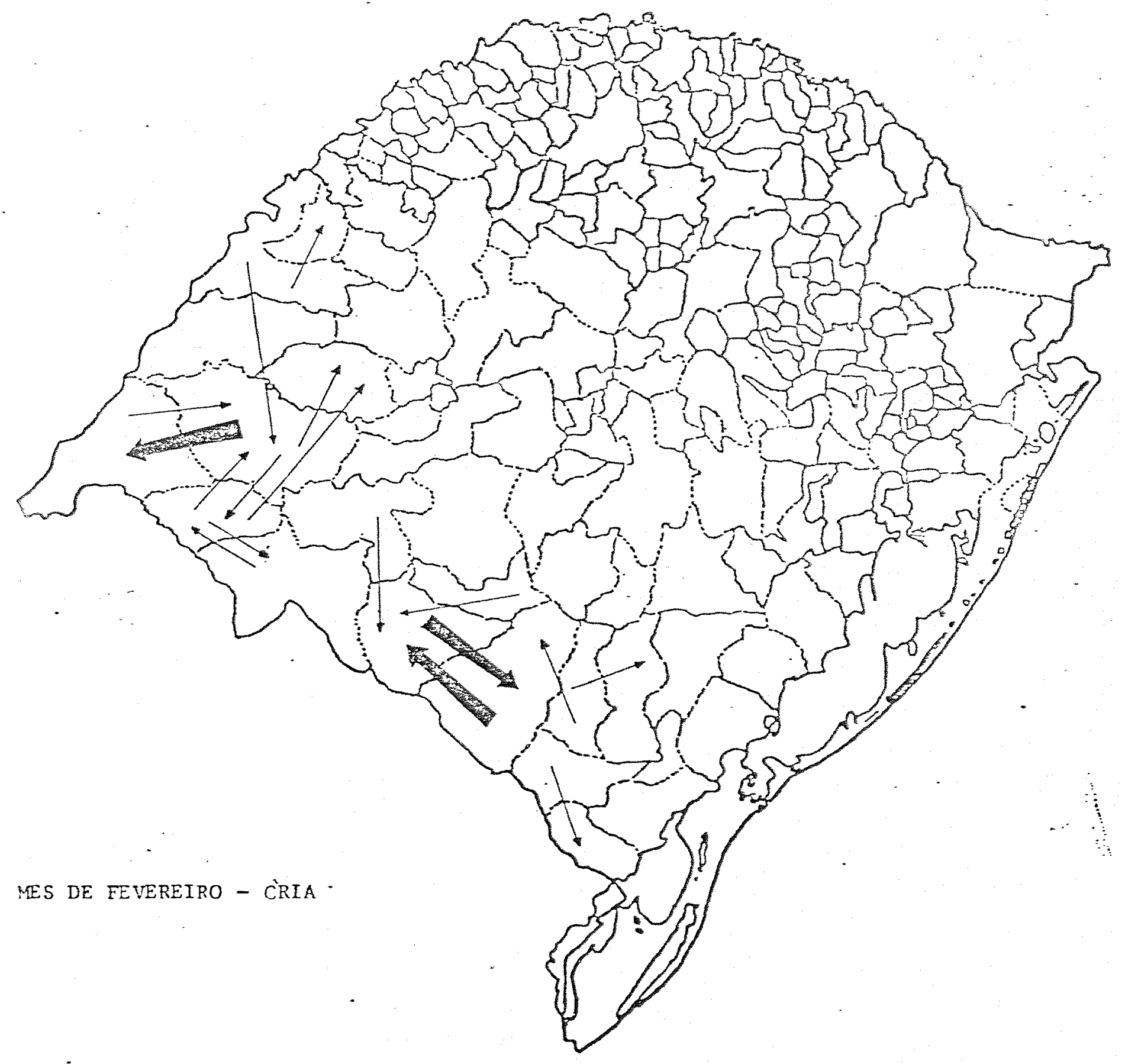




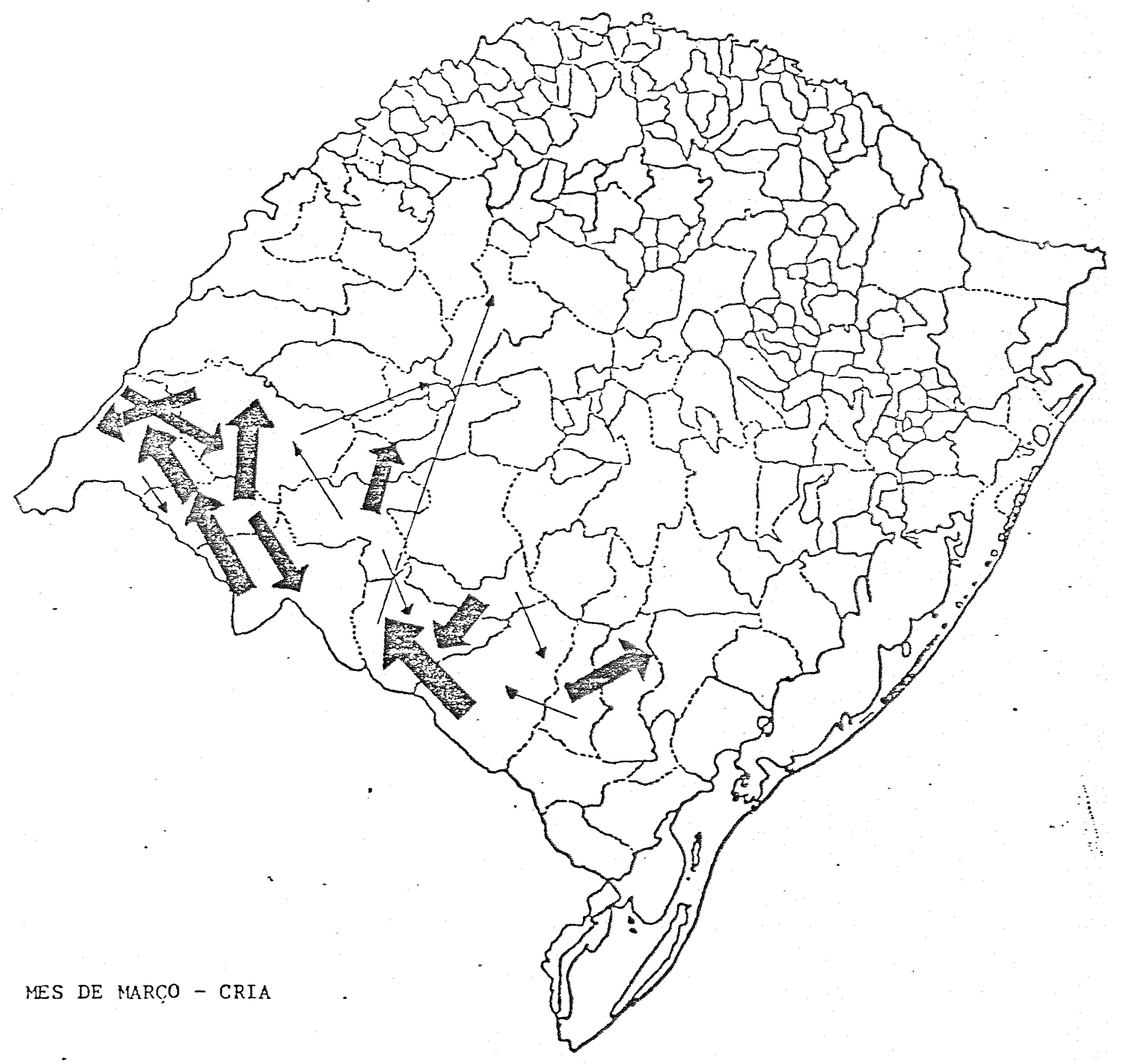




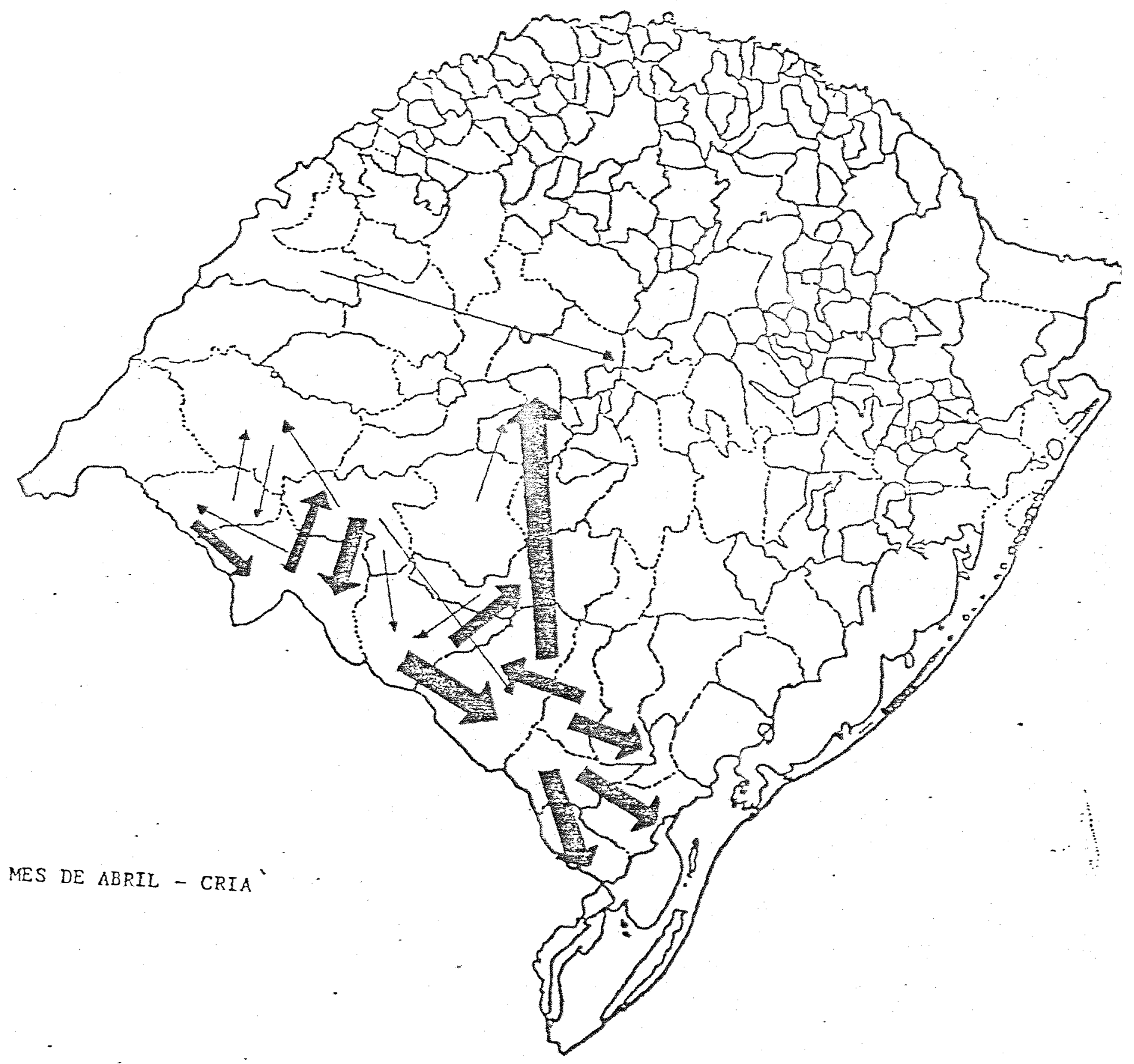




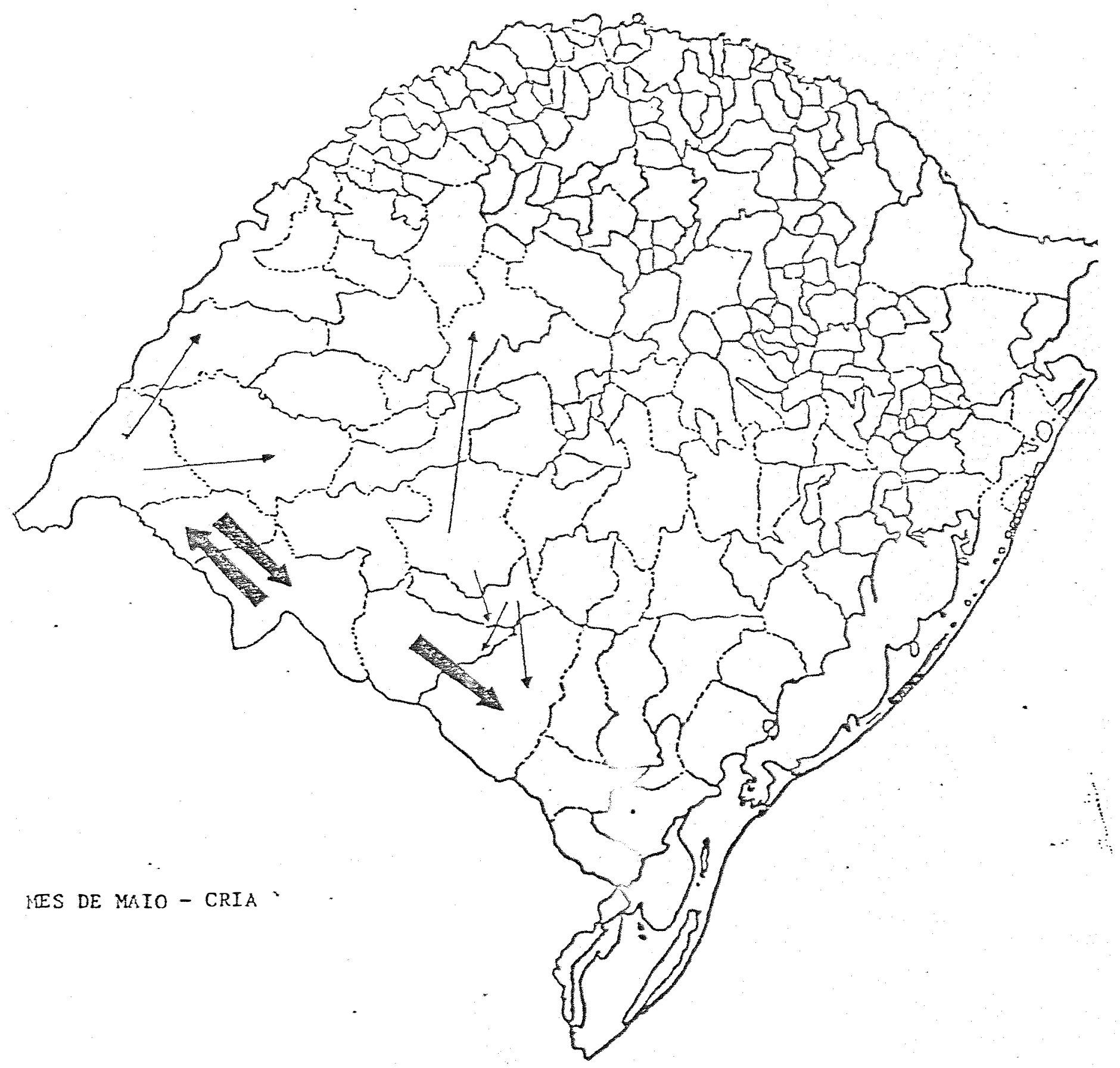




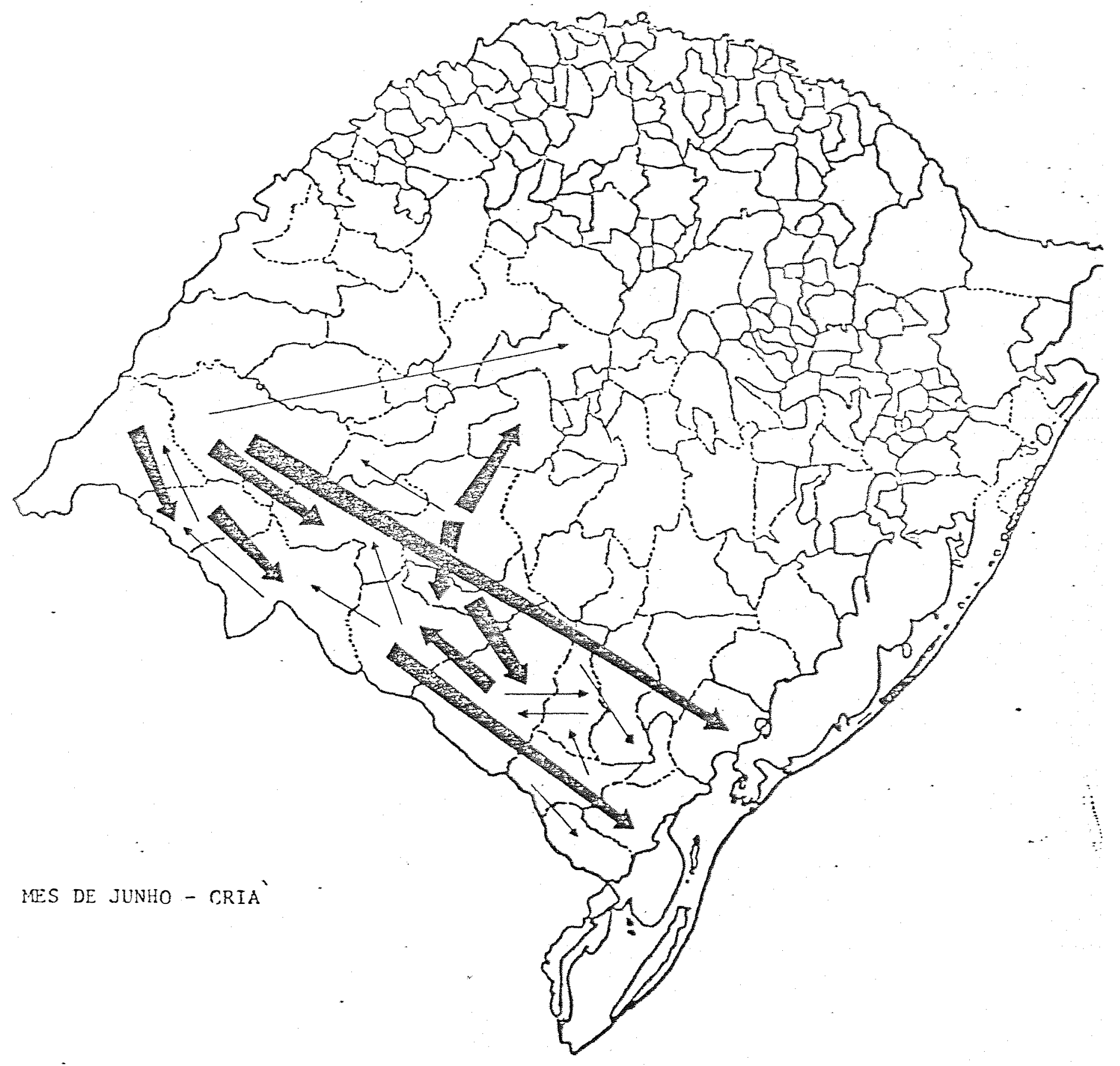




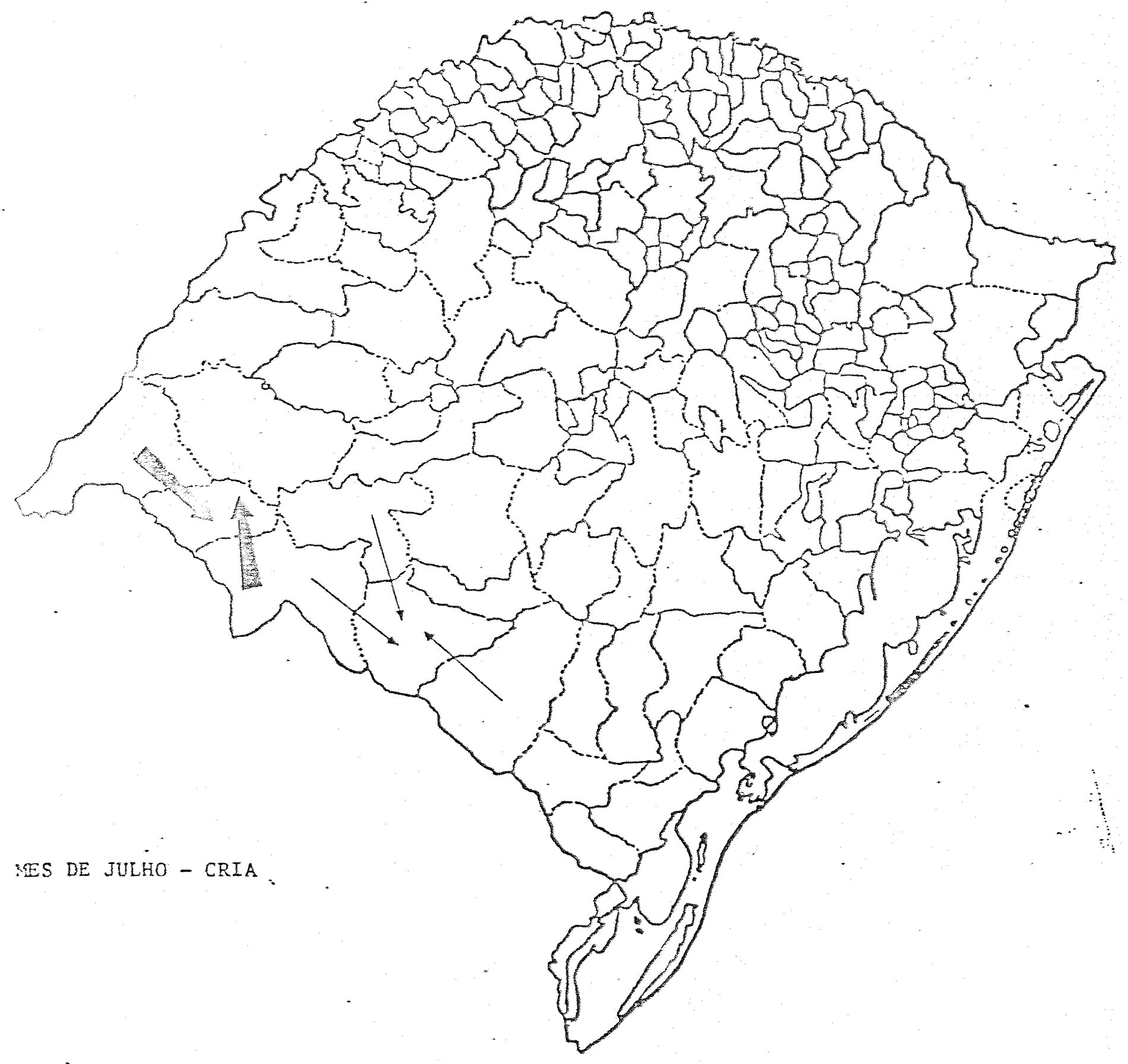




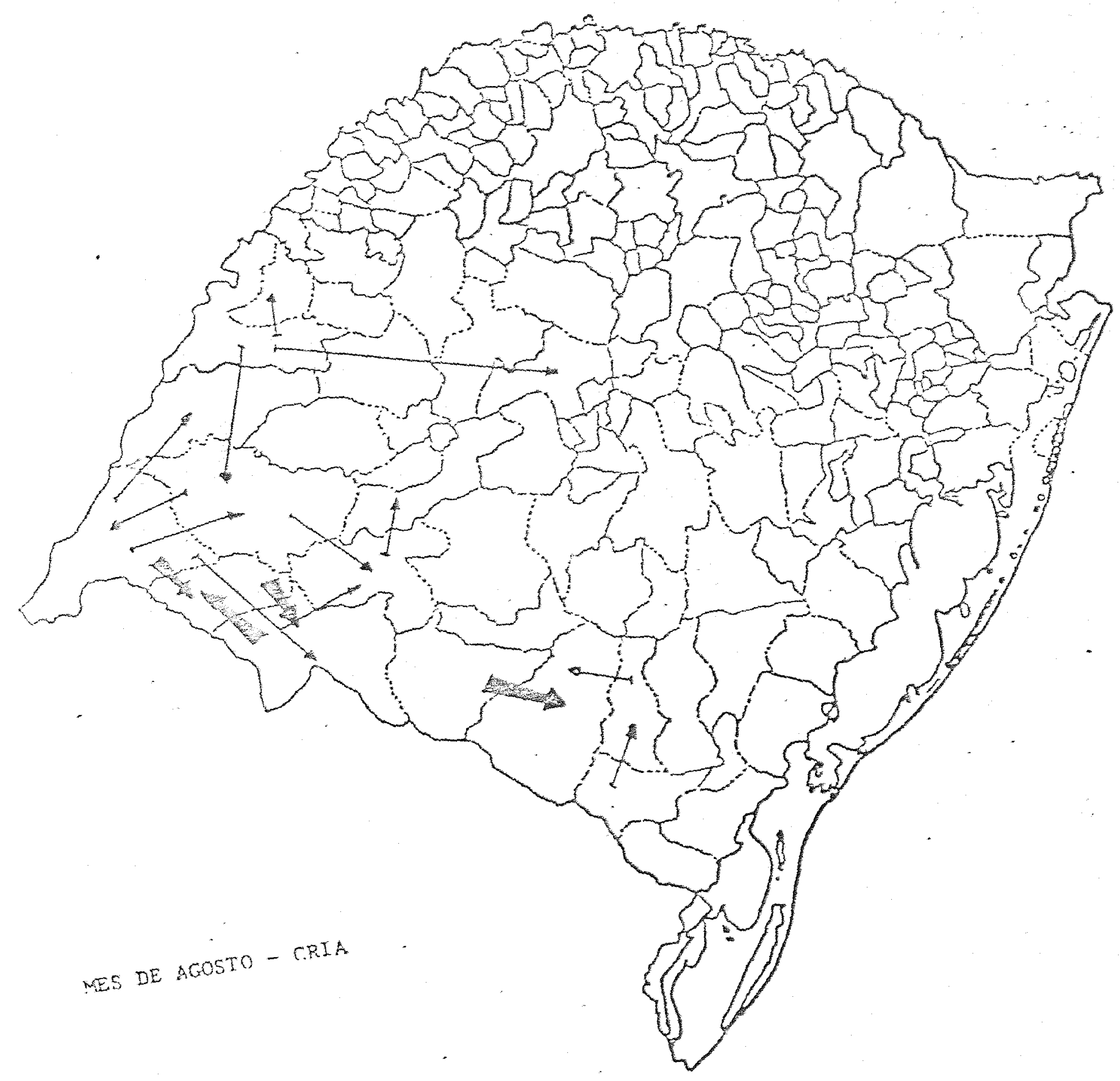




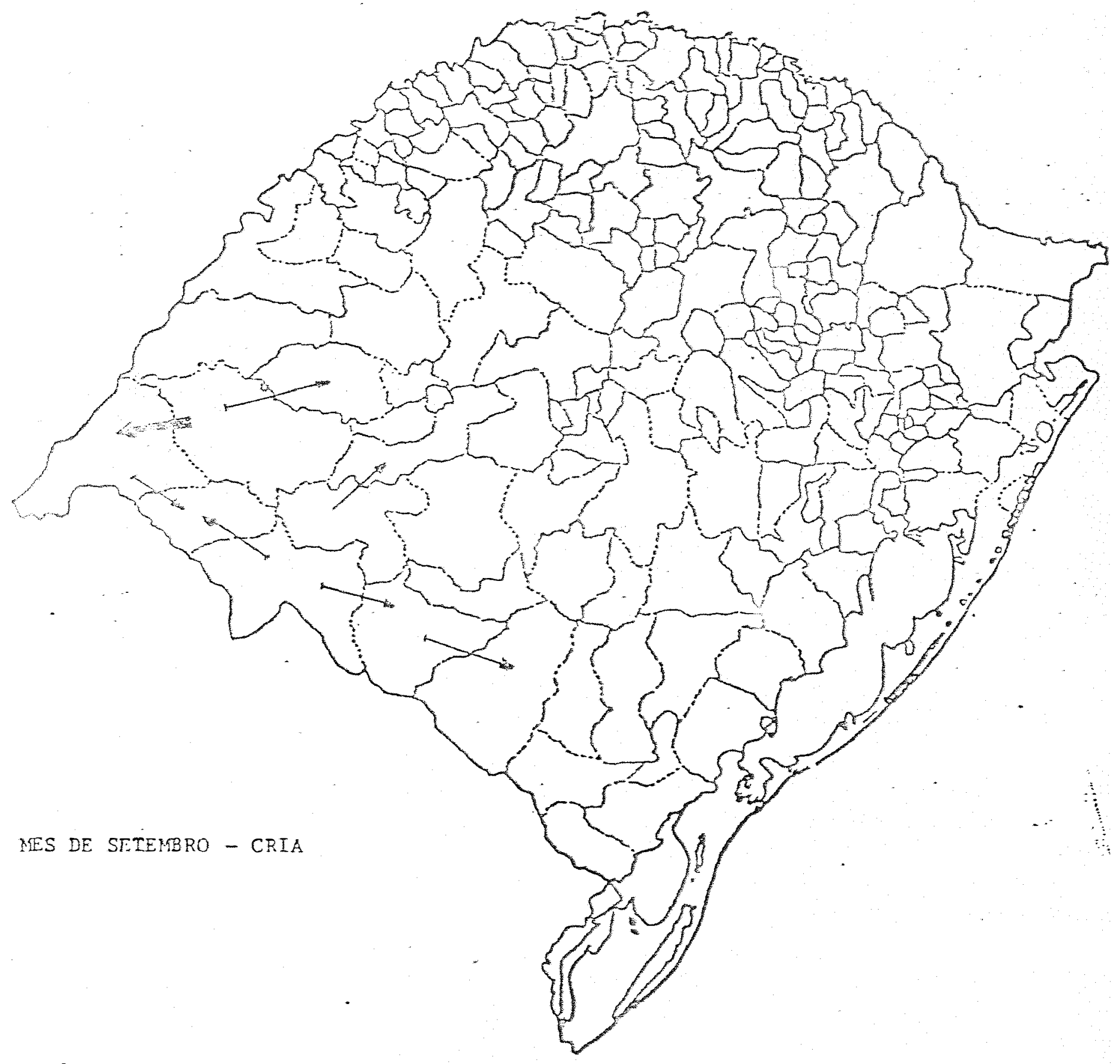




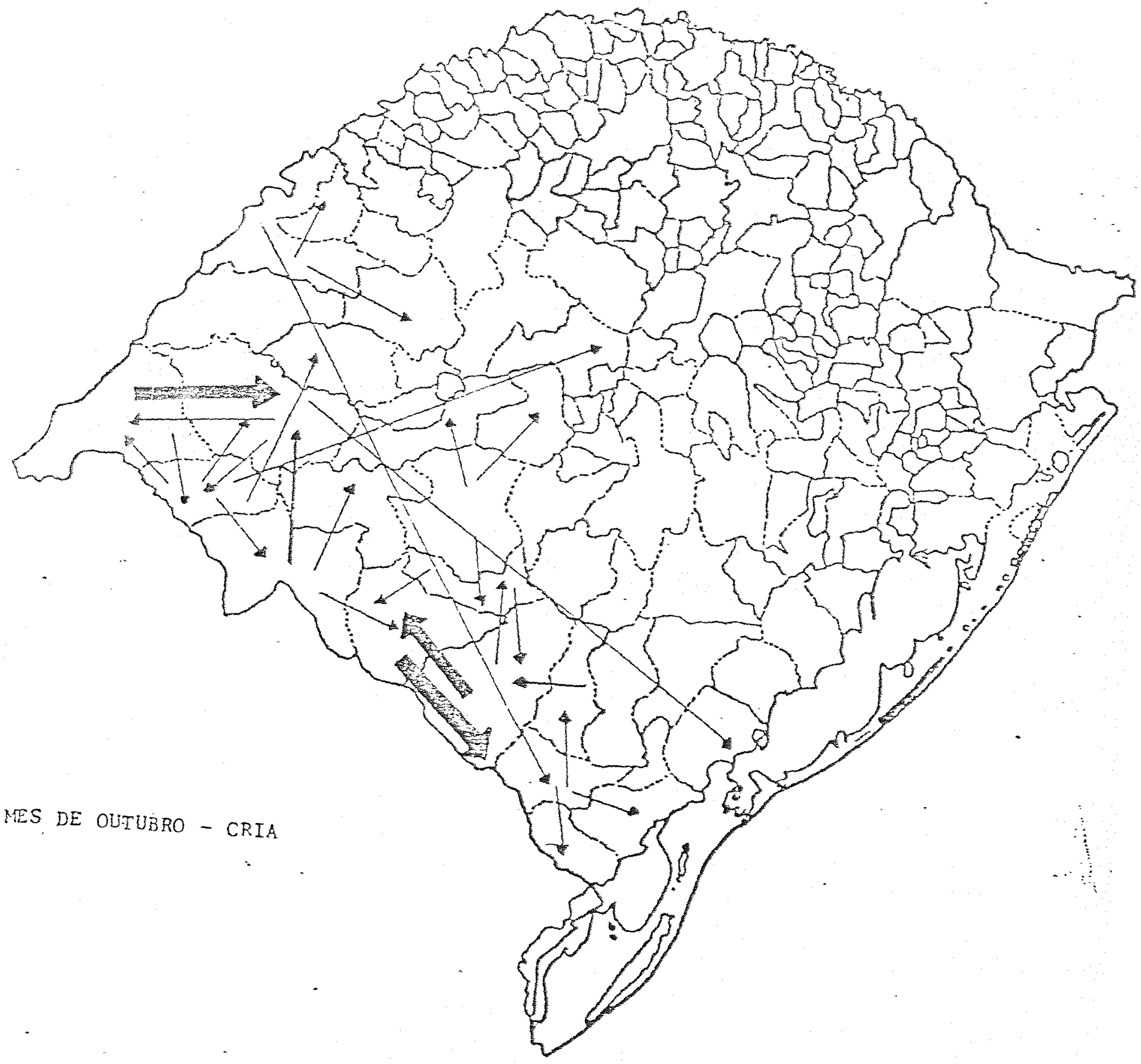




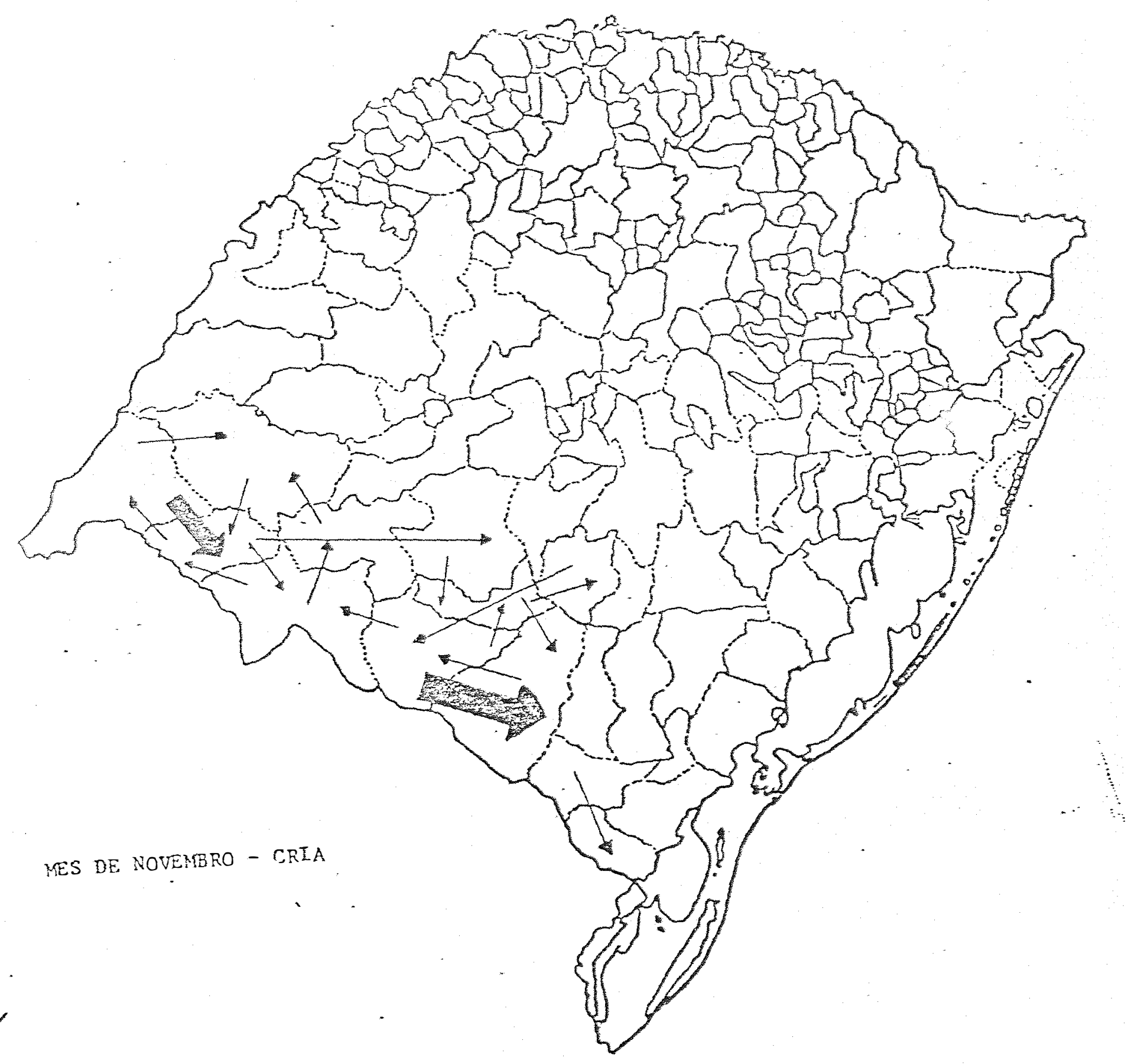




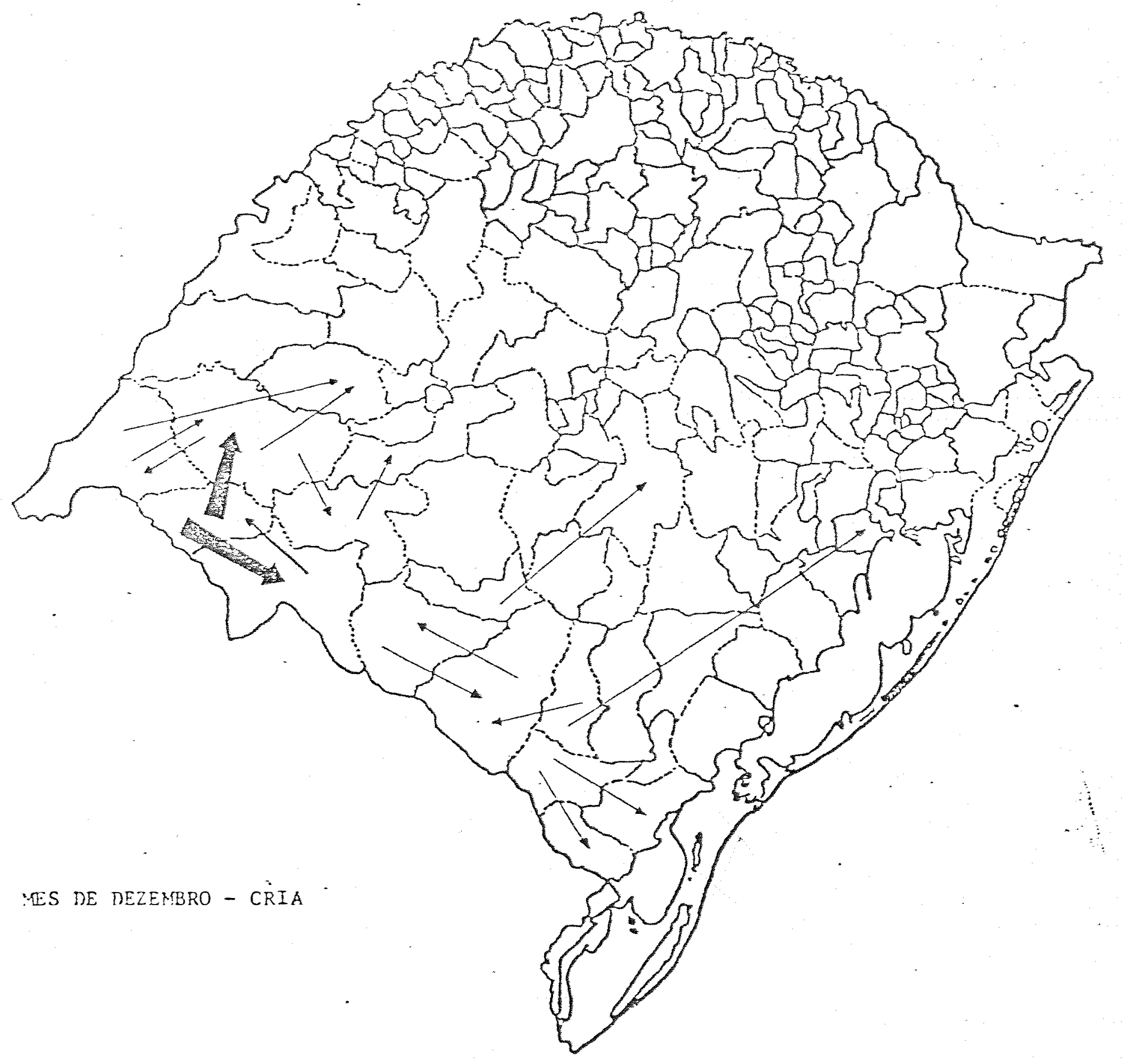

